\title{
BETWEEN MEMORY AND PAPERBOOKS: BACONIANISM AND NATURAL HISTORY IN SEVENTEENTH-CENTURY ENGLAND
}

\author{
Richard Yeo \\ Griffith University
}

"Look! What thy memory cannot contain, Commit to these waste blanks."

Shakespeare, Sonnet 77.

"Adventure not all thy learning in one bottom, but divide it betwixt thy Memory and thy Note-books."

Thomas Fuller, The holy state (London, 1642), Book III, pp. 175-6.

In his Popular lectures on scientific subjects (1873), the German physiologist, Hermann von Helmholtz, remarked that his predecessors had established ways of organizing knowledge that relieved individual memory from the burden of scientific data:

This organization consists, in the first place, of a mechanical arrangement of materials, such as is to be found in our catalogues, lexicons, registers, indexes, digests, scientific and literary annuals, systems of natural history, and the like. By these appliances, thus much at least is gained, that such knowledge as cannot be carried about in the memory is immediately accessible to anyone who wants it. $^{1}$

My aim is to show that this way of conceptualizing the relationship between memory and information has its own history. If we cast our eyes over Helmholtz's litany of tools, techniques, and publications, quite a few date from the period of the Scientific Revolution. Certainly, the Philosophical transactions of the Royal Society of London (from 1665) must find a place on such a list, as must the technical lexicons and encyclopaedias that began to flourish from the 1690s. However, for some of the seventeenth-century figures who built these early repositories, memory was not a faculty to be neglected.

Consider the following correspondence between two Fellows of the Royal Society — John Beale and Robert Boyle. In a long letter of 29 September 1663, Beale offered his views, earlier sent to Samuel Hartlib, on memory and ways to improve it. One of Beale's pervading concerns was that "We should affect, \& inwardly glory in the improvement of our owne Minds \& lay up there evry valuable advertisement, as fitter to adorne our Insides, than Frontispices, Walls, and Paper-bookes". ${ }^{2}$ This comment is representative of his advice to Boyle: namely, that a capacious and powerful memory is worth acquiring and that a constitutionally weak one can be enhanced by various methods. It seems curious to us, just as it would have to Helmholtz, that in making this case Beale warned against relying on various modes of external storage, such as paperbooks. He praised one acquaintance who "studyed Dictionaryes, \& had them 
by Hearte". He castigated students and scholars who kept "Topiques \& Common places in books, \& not in the braine". Indeed, for Beale, the function of notebooks seems to be that of prompting the memory to recall what it already should possess: "Men should take heede of engrossing in Table bookes what they ought to learne by hearte, except it be with purpose to take it off the Table booke into the Memory."

Beale's remarks echo the standard view of commonplace books in the Renaissance. As humanist scholars such as Rodolphus Agricola, Desiderius Erasmus, Philip Melanchthon, and Juan Luis Vives insisted, these notebooks were not to be treated as substitutes for memory, but rather as a means of training and improving it. ${ }^{4}$ When Francis Bacon affirmed the value of a "good and learned Digest of Common Places", he acknowledged the force of this injunction, saying that the use of "common-place books is thought by some" to invite "the memory to take holiday". ${ }^{5}$ A manual for undergraduates at Cambridge, written in Isaac Newton's student days, advised that "When you dispute, be sure you get the Arguments perfectly by heart". ${ }^{6}$ Under the same discipline, John Milton's cohorts were expected to memorize the main points in college sermons. ${ }^{7}$ The material support for this memorizing was the commonplace book. Richard Holdsworth, Master of Emmanuel College from 1637, urged students to "recorde the best of theyr studies to certain heads of future use and memorie". Anticipating that young men would eschew the bother of note taking, relying solely on their memories, Holdsworth said that this is a foolish practice, since "one booke read with Notes ... brings a better stock of Learning ... by Noting you make it intirely your own for ever after". He advised a combination of memorizing and note taking, counselling students "to remember something at least ... in every dispute, Lecture, Sermon, Speech, or Discourse, $\mathrm{w}^{\text {ch }}$ you shall heare $\&$ when you come to your studie write them downe in one of these paper bookes". Tellingly, Holdsworth did not see this practice as merely useful for short-term demands of class disputation or liturgical performance, but rather over a lifetime of reading. He regarded notebooks as custodians of quotations that should also be held in memory, so that by "frequent reading them over on evenings ... they will offer themselves to your memory on occasion". ${ }^{8}$ Notebooks prompted memory; they did not render it superfluous.

Boyle was a perfect recipient for this message, since his writings and letters reveal many confessions about his bad memory. ${ }^{9}$ In contrast, Beale claimed to possess an impressive natural memory. Before going to Eton he had been able "in secrete corners, conceald from other eyes" to memorise the key texts; and, as he told Boyle, "afterwards in Cambridge proceeding in the same order, \& diligence with their Logicians, philosophers, \& Schoolmen, I could at last learne them by hearte faster than I could read them". ${ }^{10}$ However, Beale stressed that natural endowment was fragile if not supplemented by artificial techniques and the lessons taught by Cicero and Quintilian about the importance of order and method. ${ }^{11}$ Indeed, on this point there is a hint of scare tactics in his letters to Boyle: his warning was that even a strong natural memory, if not reinforced by methodical training, will fade over the years. "I know I could once boaste of a naturall memory beyond beliefe, but I found it true, that Mr Hales foretold mee, The first grey hayre would signify the decay of 
it; And since I have had some reguard, \& ayde from some Methodes of Artificiall Memory". ${ }^{12}$ A few years later, Beale recited a story from Julius Scaliger about "Joh Suisset Calculator, (as he was denominated) ... that in the decay of his age, when he would have reviewed his owne Workes, he fell a weepeing excessively, because $\mathrm{He}$ was not able to understand, what himselfe had written. Sir, I do not threaten you with this judgement.... But, if you doe not keepe your eye frequently upon your owne margins, you may live to find the perfidiousnes of grey hayres which doe sometimes steale our own labours \& inventions out of our Memory". ${ }^{13}$

Almost twenty years before Beale's letters, some remarks from René Descartes sound more familiar to our ears. In 1648, when Frans Burman (a Dutch theological student) asked Descartes about the weakness of memory, he received this succinct reply: "I have nothing to say on the subject of memory. Everyone should test himself to see whether he is good at remembering. If he has any doubts on that score, then he should make use of written notes and so forth to help him.." ${ }^{14}$ Thus Descartes was willing to accept the limitations of memory and to suggest note taking as a strategy. This response was by no means standard in the seventeenth century: most people (not only humanist scholars) continued to regard note taking as at least in part about exercising the memory, not dispensing with it. I suggest that the seventeenth century was a crucial period in which this relationship was understood in new ways, in which the costs and benefits of relying less on individual memory (natural or trained), and more on externally stored information, were confronted.

Bacon's legacy, so palpable for the English virtuosi, hosted important discussions of the place of memory in science. ${ }^{15}$ Indeed, Bacon brings together the three components of my title - memory, paperbooks, and natural history. His classification of knowledge paired memory and natural history; but his call for richer, more detailed, collections of empirical material cast doubts on the capacity of memory to cope with the particulars of these natural histories - of animals, plants, agriculture, weather, manual arts, of life and death. In his Parasceve, he provided a catalogue of 130 such "particular histories". ${ }^{16}$ Aware of this tension, Bacon offered various responses: a reconsideration of the arts of memory; the use of lists, inventories, and tables in various kinds of paperbooks; and a new philosophical language, possibly founded on a classification of simple, or radical, notions. It is challenging to say anything new about Bacon, or Baconianism. The three themes I have mentioned have been previously identified and discussed in various contexts, as I indicate in my references. In this article, I seek to treat them as elements of a framework in which the relationship, and tension, between memory and notebooks was understood and debated by a range of individuals who can be seen as followers of Bacon's reforming programme in the sciences. I discuss some of the members of Hartlib's circle, such as Beale, William Petty, and John Pell, and also others, some of whom were associated by friendship and correspondence with this group: Boyle, Seth Ward, John Wilkins, John Ray, John Locke and, especially, Robert Hooke. ${ }^{17}$ I am not seeking to harness these people to the letter, nor even always to the spirit, of what Bacon said in his admittedly brief reflections on memory, notebooks and artificial languages. 
In any case, as Charles Webster has remarked, Bacon's writings were "as flexible and appealing as the Bible", so that his interpreters were able to choose from the intellectual emporium he bequeathed, shaping what they found with their own philosophical inclinations. ${ }^{18}$ With Bacon as a starting point, it is the views of these admirers on the subtle, and changing, relationships between memory and notebooks that I am attempting to illuminate.

\section{THE STATUS OF MEMORY}

Scholars have agreed that the prestige of a strong memory survived the waning of the Middle Ages and the birth of print culture. As Vivian Salmon remarked, "It is strange that after the invention of printing the role of memory seems to have been regarded even more highly than when the storage of information often depended on human ability to memorise". ${ }^{19}$ This overstates the point somewhat, since it is difficult to imagine anything stronger than the deference to memory in the medieval period, as analysed by Mary Carruthers in The book of memory (1990). Thomas Aquinas was lauded for his capacious memory, and in this respect he was just one embodiment of the fact that "medieval culture was fundamentally memorial, to the same profound degree that modern culture in the West is documentary". ${ }^{20}$ Before printing, there was a shift from memory to semi-reliance on written records as a means of retrieving information; but as M. T. Clanchy explains, the recourse to documents as evidence of events or contracts in preference to oral testimony was only very slowly established. By the twelfth century in England, although some regular textual records were kept, the memories of reliable witnesses were still sought, and the ceremonies marking significant agreements were choreographed to prompt memory at a later date. ${ }^{21}$ This prestige of memory remained high after the shift from scribal to print culture. Walter Ong discerned a synergy between the arrival of printing and the popularity of Petrus Ramus's tree diagrams: the later encouraged a "spatialization" of knowledge in which almost any intellectual content could be expressed in diagrammatic or tabular form; since printing facilitated the diffusion of this visual shorthand it thus supported new ways of inscribing things in memory. ${ }^{22}$ In The art of memory (1966), Frances Yates proposed that the classical art of memory made one of its final mutations in the early age of print,

turning from a method of memorizing the encyclopaedia of knowledge, of reflecting the world in memory, to an aid for investigating the encyclopaedia and the world with the object of discovering new knowledge. It is fascinating to watch how, in the trends of the new century, the art of memory survives as a factor in the growth of scientific method. ${ }^{23}$

In his Clavis universalis (1960), Paolo Rossi gave a more precise indication of how such a transformation might have occurred, especially in the thought of Francis Bacon, Descartes and Gottfried Wilhelm Leibniz. As Stephen Clucas has recently observed, Rossi's book demonstrates that the "memorial culture" analysed by Carruthers "persisted into the age of the printed book, and was still a vestigial presence 
in the early years of the European Enlightenment". ${ }^{24}$

What forms did this legacy assume in seventeenth-century England? It is important to be aware of three, often conflated, elements: the standing of the ancient art of memory; various mnemonic lessons derived from it; and confidence in the power of a strong natural memory. The classical art of memory, as described in one of the key surviving texts from the classical period, involved backgrounds or places (loci) and images (imagines). An imagined theatre or palace, replete with nooks and corners, provided a sequence of places in which the practitioner positioned images chosen to evoke the theme or argument he sought to remember. ${ }^{25}$ By the late $1500 \mathrm{~s}$, this "topical" (or "local") memory art was under attack from some of the leading humanists, such as Erasmus. In The vanity of the sciences (1569), Cornelius Agrippa argued that its techniques depended on the foundation supplied by natural memory, which itself might be cluttered by the required stock of places and images:

It [artificial memory] cannot stande without natural Memorie, whiche oftentimes is dulled with monstrouse Images, that oftentimes it causeth madnesse, and fresie in steede of profounde and sure Memories, to wite, whilest that it burdeninge the natural Memories with the Images of infinite things, and wordes, causeth them to become madde with Arte, that abide not content with the limittes of nature. ${ }^{26}$

In what might seem to be the last word, Robert Burton recommended the art of memory as a cure for melancholy — on the grounds that, like the "practice of Brachygraphy" [shorthand], it "will aske a great deale of attention". ${ }^{27}$ Yet notwithstanding the criticisms of "topical" memory, a capacious natural memory was acknowledged as an intellectual resource, and was often thought to depend, in part, on order and method - the lessons drawn from the Greek mnemonic tradition by the Roman rhetoricians, such as Quintilian. The preacher and historian, Thomas Fuller, declared in 1642 that "Artificiall memory is rather a trick than an art" — but he was renowned for his own prodigious memory feats. Samuel Pepys and John Aubrey were amazed at Fuller's ability to recite, backwards and forwards, the names of the streets and shop signs between Ludgate and Charing Cross - thus emulating the celebrated performances of the ancients, such as Simonides and Seneca. ${ }^{28}$ Fuller attributed this capacity to his strong natural memory, but Aubrey was not willing to rule out training, saying that "his [Fuller's] naturall memorie was very great, to which he added the Art of Memorie". ${ }^{29}$

The adage that quick memory and strong reason rarely coexisted often formed another point of discussion. This contrast was influentially embedded in a psychological and medical framework by the Spanish author, Juan Huarte, in The examination of mens wits (1594) - a work translated throughout Europe. Drawing on Hippocrates and Galen, but adapting the theory of the four humours to his own purposes, Huarte asserted that good understanding required a certain dryness of the brain, whereas good memory needed moisture, which allowed impressions to be made more easily. "By this doctrine", he inferred, "the understanding and memorie, are powers opposite and contrary, in short, that the man who hath a great memories, shall find a defect in his understanding" ${ }^{30}$ It may have been this kind of presumption that stimulated 
the Oxford mathematician, John Wallis, to reassert the power of natural memory. In 1685, Wallis reported to the Royal Society on "his own application of his Memory, by Night". Considering the manipulation of "Arithmetical Operations in great numbers", he said that he did this without trouble and happened to record one result — "the Square Root of 3" taken to twenty decimal places - because it was "a Surd which I might after have occasion to make use of". The astonishing point about this is that Wallis's main interest was not the achievement itself, but the hypothesis that it was more easily done at night than by day. When pressed by a visitor, he deliberately set out "by dark, in bed, without any other assistance than my Memory" to propose "to my self (at all adventures) a number of 53 places". He found "its Square Root of 27 places". Wallis concluded that "a reasonable good Memory, fixt with good attention, is capable of being charged, with more than a man would at first imagine". ${ }^{31}$

During the eighteenth century, the status of memory declined. Edward Gibbon was able to regard a low estimate of memory as characteristic of the "Moderns":

Our Philosophers have ever since affected to be astonished, that men can pass their whole lives, in acquiring the knowledge of mere words and facts, in burthening the memory without improving the understanding ... a mind capable of thinking for itself, a lively and brilliant imagination, can never relish a science that depends solely on the memory. ${ }^{32}$

Of course, no Enlightenment figure seriously contended that memory did not perform a vital role in the intellectual life of all individuals. It was agreed, for example, that the most tragic fate for a scholar was to be robbed of the command of memory - a point made with pathos by Roger North in his account of his brother, John North, Master of Trinity College, Cambridge, who died in 1683. In John's final illness "the seat of his memory was ruffled by the disease falling upon his brain"; gone now was the flow of his conversation, with its "copia of pleasant wit.... He seemed as an high-flying fowl with one wing cut. The creature offers to fly, and knows no cause why he should not, but always comes with a side-turn down to the ground" ${ }^{33}$ Even Locke, who denounced rote learning in the education of the young, acknowledged that memory "is of so great moment, that where it is wanting, all the rest of our Faculties are in a great measure useless". ${ }^{34}$ Yet memory was weak and unreliable, and so various supports had to be employed, such as methodical and orderly use of notebooks. ${ }^{35}$

Gibbon was surely thinking of Jean le Rond d'Alembert's "Preliminary discourse" (1751) to the Encyclopédie, in which he adopted Bacon's tripartite division of knowledge. In the Advancement of learning (1605), Bacon classified knowledge in terms of governing mental faculties, so that Memory, Imagination and Reason control, respectively, the subjects of History, Poetry and Philosophy. ${ }^{36}$ In glossing Bacon, d'Alembert suggested that having thus "designed the tree of sciences, one would be able to construct the tree of men of letters on the same pattern". This typology of intellectual pursuits identified memory as the appropriate faculty for the scholar, reason for the philosopher, and imagination for the poet. D'Alembert accepted that 
"Memory includes the primary material of all our knowledge", but he regarded its function as "purely passive and almost mechanical collection". ${ }^{37}$ This was the conventional definition, restated by Bacon; but by the mid-eighteenth century (as Gibbon noticed) the auxiliary role of memory was used as an opportunity to laud the analytical power of reason and the creative energy of imagination.

\section{THE BACONIAN LEGACY: MEMORY AND NATURAL HISTORY}

In scholastic accounts, based mainly on Aristotle, the work of memory was, as Bacon put it, close to the start of the "intellectual process". External impressions made on the senses were fixed as images in memory "just as they present themselves"; memory was "affected by individuals only", until "the mind recalls and reviews them". ${ }^{38}$ Whereas reason generated mathematical and demonstrative knowledge (scientia), memory was responsible for a lower class of knowledge, characterized by descriptive accounts of particulars and narratives of events. Thus historia included natural history, considered broadly as comprising not only botany and zoology, but also descriptions of the crafts and techniques that put Nature to various uses. Thomas Hobbes made the distinction in these blunt terms: "The Register of Knowledge of Fact is called History" whereas the "Registers of Science ... contain the Demonstrations of Consequences of one Affirmation, to another". ${ }^{39}$ Accordingly, subjects such as civil and natural history could not aspire to the status of scientia. Yet Bacon did not disparage this lower kind of knowledge: for him, a vast collection of natural history was the necessary starting point for a natural philosophy that might ascend to general laws and causal explanations. ${ }^{40}$

This function of memory as a repository of particulars did not necessarily mean that it was undervalued. Together with polymathic scholars, early modern naturalists figured in the repertoire of stories about individuals exhibiting prodigious memories. One example is Gregorio Bolivar, a Spanish Franciscan living in South America in the early 1600s. In a record of conversations with Bolivar, Johannes Faber, secretary of the Academy of the Lincei in Rome, observed how his notes triggered his exceptional memory: "I swear to you, my reader, that what I derived from him up to now from his mouth and notes, he described with good recollection and without the aid of any book. And that he brought them together with the aid of a sort of compendium only." ${ }^{41}$ John Ray, the leading English naturalist of the seventeenth century, was assessed in similar terms by his friend, the physician, Tancred Robinson: "I am overjoyed that so vast a Memory, so exact a Judgment, and so universal a Knowledge, will be employ'd in compiling a general History of Plants, an Undertaking fit only for your extraordinary Talents." ${ }^{42}$ Yet a different attitude is apparent in Ray's own reflections on his collaboration with Francis Willughby. Writing to Robinson in 1685, he said:

If I had Mr Willugby's Notes, I doubt not but I could find out a more exact Description of the Orphus than will be met with in Authors; for that Fish I am sure was more than once described by us. But it is almost impossible to procure a Sight of them.... I did describe most of the Animals we met with in our Travels; but 
all my Notes of high and low Germany were unfortunately lost. ${ }^{43}$

Ray knew that lost notes meant lost information.

Bacon's insistence on a new empirical foundation for natural history put extraordinary pressure on memory. In his Naturalis historia (77 A.D.), Pliny the Elder had already sounded the alarm about the sheer magnitude of relevant material. Pliny boasted that his work gathered 20,000 items of information drawn from 2000 volumes by one hundred authors. But Bacon's demand in the Novum organum for "a greater abundance of experiments" and "new particulars" was a call for open-ended collection of data. ${ }^{44}$ Yates suggested that Bacon, aware that this would require careful methods of collecting and ordering, contemplated some application of the art of memory:

It was therefore roughly speaking the normal art of memory using place and images which Bacon accepted and practised. How he proposed to improve it is not clear. But amongst the new uses to which it was to be put was the memorizing of matters in order so as to hold them in the mind for investigation. This would help scientific inquiry, for by drawing particulars out of the mass of natural history, and ranging them in order, the judgement could be more easily brought to bear upon them. ${ }^{45}$

I believe that this statement needs qualification in one important respect. Bacon explicitly recognized the problem of an intolerable load on memory, one not able to be relieved by "the normal art of memory". In fact, Yates's summary better expresses the position of Jean Bodin in his advice on how to manage historia. In his Methodus ad facilem historiarum cognitionem (1572) he declared that the variety of histories and the events and information they contain were too great for retention in the memory; hence "similar instances of memorable matters should be placed in a certain definite order" so that memory can be a "treasure chest" of examples and precepts. ${ }^{46}$ My point is that Bacon went further towards externalizing the data of natural history, distancing it from individual memory. This is what he said in the Novum organum:

But even after such a store of natural history and experience as is required for the work of the understanding, or of philosophy, shall be ready at hand, still the understanding is by no means competent to deal with it off hand and by memory alone; no more than if a man should hope by force of memory to retain and make himself master of the computation of an ephemeris. ${ }^{47}$

In this connection, Bacon emphasized the function of writing - not only in the transmission of knowledge but also in its discovery. In the passage just cited, he went on to urge that "Now no course of invention can be satisfactory unless it be carried on in writing". He explained that the intellect was unable to do anything when confronted with an "army of particulars" unless these were brought into some order, such as provided by "Tables of Discovery, apt, well arranged". With information stored and ordered in writing, it would then be possible for the mind to "set to work upon the helps duly prepared and digested" in these tables. ${ }^{48}$

In his Francis Bacon: From magic to science (1968), Rossi explored what this use 
of tables might have meant. Whereas Yates interpreted Bacon as engaging with the classical art of memory, based on "place and images", Rossi argued that he largely dispensed with the use of images (or "emblems"). In his view, Bacon transferred the concept of "place", and its concomitant emphasis on order, to the organization of data in written tables and lists: "[Bacon] adapted the art of memory to other than traditional ends. He devised the tables or instruments of classification to organise reality and thus enable the memory to assist intellectual operations." ${ }^{49}$ This identification of a reformed natural history as a burden on natural memory called for reliance on external aids. In The advancement of learning, and at more length in the expanded Latin version of this work, De augmentis (1623), Bacon consolidated these points:

The great help to the memory is writing; and it must be taken as a rule that memory without this aid is unequal to matters of much length and accuracy; and that its unwritten evidence ought by no means to be allowed. This is particularly the case in inductive philosophy and the interpretation of nature; for a man might as well attempt to go through the calculations of an Ephemeris in his head without the aid of writing, as to master the interpretation of nature by the natural and naked force of thought and memory, without the help of tables duly arranged. ${ }^{50}$

This insistence on writing as crucial for the collection and arrangement of natural histories broke with Bodin's assumption that individual memory should remain the custodian of "memorable things". Bacon established the groundwork for the collaborative collection, storage and retrieval of information that his project demanded. Could this task be handled by the prevailing note taking practices? And would this be a matter of notes aiding memory, or relieving it?

\section{PAPERBOOKS AND NATURAL HISTORY}

In the Novum organum, Bacon anticipated the objection that his method of inquiry did not offer an advance upon older models: "For the ancients too, it will be said, provided at the outset of their speculations a great store and abundance of examples and particulars, digested the same note-books under heads and titles, from them completed their systems and arts ... but thought it superfluous and inconvenient to publish their notes and minutes and digests of particulars." ${ }^{51}$ Bacon's answer was that notebooks were indeed crucial to his project, and that they should be kept, and updated, as correctives to the very generalizations that they served to support.

In stressing the importance of writing for the advancement of knowledge, Bacon endorsed a role for notebooks in natural history. In his essay, "Of travel", he commented that "It is a strange thing, that in sea voyages, where there is nothing to be seen but sky and sea, men should make diaries; but in land-travel, wherein so much is to be observed, for the most part they omit it; as if chance were fitter to be registered than observation. Let diaries therefore be brought in use". ${ }^{52}$ Given that the humanist commonplace book was the notebook of choice for the educated élites, Bacon's call for the use of diaries and journals is significant. In the De augmentis, he says that the Romans used both "Annals" and "Journals". As well as marking different periods 
of time (respectively, year versus day), these two forms dealt with different matters: the former recorded public events whereas the latter registered matters pertaining to the city or to aristocratic families. Bacon continued: "But the journals of Alexander's house expressed every small particularity, ... everything, whether of greater or less concern, was promiscuously entered in the Journals as it passed." ${ }^{53}$ This last phrase closely resembles the description of merchants' "waste books" in which sales and purchases were entered as they occurred, before being entered into another book - often called a ledger or journal, arranged into the double columns as influentially recommended by Luca Pacioli in his De computis et scripturis (1494). ${ }^{54}$ Indeed, Bacon gave considerable thought to the use of his own notebooks. In 1608 he entered the following reflection in one of these: "I think it wilbe more ready and more easy to make these divisions of paper bookes fewer and lesse curious and more sorted to use than to Art: and therefore first to have Commentarius Solutus like a Marchant's wast booke where to enter all maner of remembrance of matter, fourme, business, study, towching my self ... $\mathrm{w}^{\text {th }}$ out any maner of restraint." He then accepted the importance of having "another booke like to the marchants leggier booke" in which things worth keeping were entered more carefully. From this notebook, selected information could be classified, and "thinges of a nature" could be entered "under fitt Titles". ${ }^{55}$ This is pertinent, especially given Bacon's demand that "every small particularity" of natural objects and events be carefully noted. There was a danger that such a mode of collection would yield nothing more than a chaos of miscellanies. In his introduction to Sylva sylvarum, William Rawley explained that Bacon admitted that perhaps he should not have "published this Naturall History: For it may seem an indigested Heap of Particulars; and cannot have that Lustre, which Books cast into Methods have" ${ }^{56}$ This is where commonplacing under topics became crucial as an organizing method.

In the mid-twentieth century, literary scholars such as William Crane and Karl Wallace underscored similarities in terminology and method between textual commonplacing and Bacon's approach to natural history: in essence, both collect and arrange material under appropriate Heads. ${ }^{57}$ Rossi acknowledged this scholarship when he highlighted Bacon's transfer of humanist commonplacing methods to science. To some extent, of course, there was nothing surprising about this extrapolation since the notion of copia rerum (as well as copia verborum) was a standard element in Renaissance rhetorical theory, as represented in the writings of Agricola, Melanchthon and others. In his De disciplinis (1531), Vives included "things" as well as words among the examples of matter to be entered in a commonplace book. As Ann Moss puts it, the things comprised "lists of famous men, cities, animals, plants, and minerals". ${ }^{58}$ Although the natural world was full of things (res) to be commonplaced, Bacon sought a natural history that did not replicate the tedious and predictable use of commonplace books, "all of them carrying merely the face of a school, and not of a world; and referring to vulgar matters and pedantical divisions without all life or respect to action". ${ }^{59}$ Yet this is precisely what he found in the natural history of his day: it was too reliant on textual authorities and often amounted to nothing more 
than a confused ensemble of parable, folklore and unverified reports - indeed, akin to some of the material in Bodin's general histories. When Bacon called for the discarding of "citations or testimonies of authors", of "disputes and controversies ... everything in short which is philological", he was attempting to shift natural history out of the literary domain in which it was currently pursued. ${ }^{60}$ The editor of Baconiana (1679) recognized this:

And further, as his Lordship noteth, too many of these Histories were at first framed rather for Delight, and Table-talk, than for Philosophy. Stories were feigned for the sake of their Morals; and they were frequently taken upon groundless Trust; and the later Writers borrowed out of the more Ancient, and were not Experimenters, but Transcribers: And such a one was Pliny himself.... ${ }^{61}$

How could natural history be conducted within the commonplace method? In discussing Bacon's extrapolation of key concepts such as "Promptuary" and "Topics", Rossi contended that "For Bacon this procedure undergoes very little change when applied to the scientific sphere". ${ }^{62}$ We need to be more precise about this. When Bacon takes these concepts into natural history they are subtly transformed: the promptuary is no longer a treasury of arguments ready to be applied in various rhetorical situations; rather, it is a storehouse of observations and experiments, loosely and tentatively grouped under specific, or "particular", topics of a history, say, that of heavenly bodies, air, or fish. Against the background of her fine analysis of the humanist commonplace method, Moss argues that in propounding a method of discovery, Bacon rejected the traditional "places of proof" in favour of "places of enquiry: that is to say, headings for receptacles never yet filled and which will function as prompters to research into the further questions which are raised by each new advance in knowledge" ${ }^{63}$ Crucial here is Bacon's radical point that "the invention of arguments is not properly an invention; for to invent is to discover that we know not, not to recover or resummon that which we already know". ${ }^{64}$ This implied that the commonplace method in natural history would be far more open-ended than usually understood: the particulars collected were not expected to reinforce a larger authoritative framework. The challenge was one of ensuring that such particulars did not produce a miscellany. This, I think, is one reason why Bacon affirmed that his stress on writing applied a fortiori to "inductive philosophy and the interpretation of nature". ${ }^{65}$

I want to consider two problems raised by the synergy between commonplacing and Baconian natural history. The first is about how information should be collected — in brief or copious form; the second concerns who should collect it — individuals or groups.

Although Bacon understood collection of material in notebooks as a relief to memory, this of itself did not answer the requirements of his natural history. Bacon was caught between the appeal of brevitas and the seduction of copia. The need to balance these two concepts was a standard requirement of rhetorical training, but it is not clear how this even-handedness could be accomplished in Baconian natural history. There were plenty of grounds on which he was prepared to cull its usual 
stock: "that superfluity of natural histories in descriptions and pictures of species, and the curious variety of the same, is not much to the purpose." ${ }^{\prime 66}$ However, his call for meticulous gathering of everyday or "common things" more than compensated for any saving. There can be no doubt that Bacon required copious material as a basis for comparative analysis. As he said, in "the history which I require and design, special care is to be taken that it be of wide range and made to the measure of the universe". ${ }^{67}$ At the same time, he was cautious about how such material was to be stored: it should be "written succinctly" because this focused the mind. Recommending "writing in Aphorisms", he explained that unless these were vacuous, they "cannot be made but of the pith and heart of sciences" ${ }^{68}$ Lorraine Daston has argued persuasively that the emphasis on brevity played an important role in shaping the modern notion of the "fact": when shorn of rhetorical ornamentation and theoretical presuppositions, brief empirical observations and experimental reports could be treated as discrete bits of information. These could then be more easily moved around to serve various arguments and disputes. Daston also suggests that pithy "facts" helped both attention and memory. I am not sure that her point holds for memory, at least not as a general rule. Certainly, Baconians agreed that marvellous facts and artificially produced phenomena might well concentrate the mind and cement a memory. ${ }^{69}$ However, the task of combining and recombining bits of information would surely add to the burden of memory. As the standard rhetorical manuals warned, even brief facts were more difficult to remember if not strongly bound together. In terms of what Bacon sought to do with data, such particulars, even if divorced from their original contexts, needed to be placed under Heads so as to prevent confusion or, as he said, so that "infinity is at once cut off, and the memory has not so far to range". ${ }^{70}$ Bacon did not want loose pieces of data: his preference for pithy information was at least in part conditioned by his wish for succinct display in tables, under topics, that permitted the mind to begin comparative judgments. He did not think that all this reshuffling could be done by memory.

During the Renaissance, individuals kept commonplace books as personal notebooks; Baconian natural history was avowedly collaborative. Undoubtedly there is a tension here. ${ }^{71}$ Nevertheless, although commonplaces were assembled by individuals in private notebooks, they comprised widely endorsed topoi spotted in canonical texts. Precisely because of this, it was assumed that these notebooks could be shared among friends. ${ }^{72}$ In addition, humanist scholars sanctioned the practice of delegating note taking to amanuenses. To mention just one well-studied example, Gabriel Harvey acted as a scholar-secretary, supplying classical passages relevant to the political arguments of his employers. ${ }^{73}$ Anthony Grafton has also drawn attention to a project, directed by Matthias Flacius Illyricus, professor of Hebrew at Wittenberg from 1544, involving a team of compilers assembling large ecclesiastical histories. Indeed, Grafton suggests that the collaborative, yet hierarchically, governed collection of information outlined in Bacon's New Atlantis may have been a model. ${ }^{74}$ Given this, it is remarkable that Bacon himself was very cautious about collective note taking, arguably to the extent of jeopardizing his own plea for collaborative 
gathering of empirical information.

Having been asked by Fulke Greville (the first Lord Brooke) about the delegation of note taking for a large project, Bacon assumed that this question applied equally to natural, civil or military history, although he described Greville's project as "the Study of Humanity" ${ }^{75} \mathrm{He}$ then posed the issue in these terms: "He that shall out of his own Reading gather for the use of another, must (as I think) do it by Epitome, or Abridgment, or under Heads of Common Places." He immediately disparaged abridgement, but granted that it can be useful to have a condensed version of, say, Euclid's Elements. The problem was that the person making abridgements, or epitomes, must know the subject well. Hence it would be risky to delegate this task to assistants. In any case, Bacon made it clear that he preferred the other mode of note taking: "I hold Collections under Heads and Common Places of far more profit, and use; because they have in them a kind of Observacion." However, the problem of how to delegate such note taking remained: an assistant, set to work on commonplacing any list of authors, was likely to collect under "many idle Heads", easily sufficient "to fill his paper-Book ... full of idle marks". Bacon advised that such assistants use only Heads appropriate to the task, or, in any case, "far fewer" than found in the standard collections, such as those made by "common Book-makers that follow an Alphabet". ${ }^{76}$ Yet even with these precautions, Bacon questioned the very notion of delegation:

Therefore to speak plainly of the gathering of Heads, or Common Places; I think, First, that in general one Man's Notes will little profit another, because one man's Conceit doth so much differ from another's; and also because the bare Note itself is nothing so much worth, as the suggestion it gives the Reader. ${ }^{77}$

If this caveat had force in the case of a delegated study of texts, then it surely had implications for natural history. Yet notwithstanding Bacon's concerns about shared note taking, his followers regarded this practice as crucial to the new philosophy. Moreover, as I suggest later, some of them believed that his other problem - balancing copia and brevitas - could be resolved in a fashion that assisted both memory and reason.

\section{SHARING NOTES ABOUT NATURAL HISTORY}

Members of the Hartlib circle, the Oxford Philosophical Society, and the Royal Society agreed that the Baconian natural history project entailed a collaborative effort. This was envisaged as a two-stage process: first, collate and condense the information already available; and second, orchestrate the collection of new material. Both stages involved note taking, understood as variants of the method of commonplacing. Hartlib's correspondents used the term 'commonplace' in connection with the abbreviation of material for easy reading: "A man should reduce Helmont into commonplaces, collecting all homogeneal passages upon one and the same subject under one title through the whole booke." ${ }^{78}$ Hartlib suggested that some authors could be "read by way of Common-places, that is to say, the chiefe things et most 
remarkable in them, ought to be pickt out, et brought into the Heads of the Commonplaces of that science wherunto they belong". ${ }^{79}$ William Petty's Advice (1647) to Hartlib formalized this preparatory commonplacing in a set of eight desiderata, included the following: that "all the Real and Experimental Learning" should be "sifted and collected"; the "appointment of able Readers" suitably instructed "with certain and well-limited Directions". The aim was that "Out of all these Books one Book, or great Work, may be made, though consisting of many Volumes". 80

The scale of such ambitions should not be underestimated. In 1640, Hartlib referred to "Harrisons booke-Invention" which promised "to give a perfect Index upon all Authors or a most Real and judicious Catalogue Materiarum out of all Authors to represent totum Apparatum Eruditionis which is extant in what Bookes soever". ${ }^{11}$ When Jan Comenius was in England, he heard about this "wonderful invention" which would make it possible to reduce "into one Index all the authors of merit in any given language". ${ }^{82}$ Clearly excited by this prospect, Comenius wanted to meet the inventor:

I would fain meet Harisson and learn fuller details from him about his project, but I was told that he was out of London ... I hear (but this is only hearsay evidence) that he already has a list of some 60,000 authors whose works he proposes to index. My friends here think that a considerable number of students from the two Universities will be deputed to assist Harisson. Under his supervision they might index the authors assigned to them. ${ }^{83}$

Recently, Noel Malcolm has rescued Thomas Harrison from near oblivion (and misidentification) to show that his proposal involved the use of notes on moveable slips of paper (anticipating index cards) which were to be stored alphabetically in a specially designed cabinet, or as Harrison called it, "Arca studiorum" ("The ark of studies"). ${ }^{84}$ As Comenius reported, the project required the division of labour and the supervision of many assistants — precisely the scenario that worried Bacon. As Comenius understood it, with this giant index it would "be possible readily to ascertain the opinions of divers authors on any specific point of interest". Yet the basic units of this group exercise in distillation of information and knowledge are not clear. Comenius's focus on "opinions" does not seem to capture the more fundamental units, possibly simple propositions, that Harrison implied might be recombined in new ways. ${ }^{85}$

Harrison's project may have been at once ahead of its time and insufficiently developed, but versions of his general aim are apparent among those interested in the communication of scientific knowledge. John Wilkins, the Warden of Wadham College, Oxford, convened the Philosophical Society in 1648. Speaking in 1652, his colleague, Seth Ward, the astronomer and theologian, explained that "our Clubb" had embarked on this task: "we have ... gone all over all or most of the heads of naturall philosophy \& mixt mathematics collecting onely an history of the phenomena out of such authors as we have in our library ... our first business is to gather together such things as are already discovered and to make a booke with a general index of them.." ${ }^{\text {"A }}$ Among Hooke's papers in the Royal Society, there is a manuscript entitled 
"Proposalls for $y^{\mathrm{e}}$ Good of $\mathrm{y}^{\mathrm{e}}$ R.S.". It contains the following prescription: "That a certain number of $\mathrm{y}^{\mathrm{e}}$ Society be appointed to read over Antient \& modern authors that treat of naturall \& Experimentall knowledge, each person making choice of $y^{\mathrm{e}}$ book he will read over and epitomise as to all things considerable for $\mathrm{y}^{\mathrm{e}}$ Societys Designe." ${ }^{87}$ Such plans for collective note taking were susceptible to the problems Bacon had identified in his letter to Greville. Petty seemed to be expecting the worst when stressing that each book be read "by two several Persons a-part, to prevent Mistakes and failings from the said Directions". ${ }^{8}$

In the second stage of this programme, new information was to be gathered by means of new observations and experiments. There was a feedback loop here, since whenever novel information was produced it had to be collated and, ideally, condensed. But first it had to be acquired. And again, there was no doubt that this demanded a collaborative endeavour. In the Parasceve, Bacon maintained that the natural and experimental histories could not be accomplished single-handedly because "the materials on which the intellect has to work are so widely spread, that one must employ factors and merchants to go everywhere in search of them and bring them in" ${ }^{89}$ In his History of the Royal Society (1667), Thomas Sprat followed this injunction almost to the letter:

Their manner of gathering, and dispersing Queries is this. First they require some of their particular Fellows, to examine all Treatises, and Descriptions, of the Natural, and Artificial productions of those Countries, in which they would be inform'd. At the same time, they employ others to discourse with the Seamen, Travellers, Tradesman, and Merchants, who are likely to give them the best light. Out of this united Intelligence from Men and Books, they compose a Body of Questions, concerning all the observable things of those places.... They have compos'd Queries, and Directions, what things are needful to be observ'd, in order to the making of a Natural History in general: what are to be taken notice of towards a perfect History of the Air, and Atmosphere, and Weather. ${ }^{90}$

Here the Heads of the commonplace tradition have become topics of natural history and experimental inquiry - often along the lines of Bacon's specific topics. Another strategy, as Sprat indicated, was to turn Heads into directions or queries. Again, there were Hartlibian precedents. In The legacy of husbandry (1652) there is an "Alphabetic of interrogatories" consisting of a list of items (mainly, but not solely, plants and animals) from "Apricocks" to "Wormes". For each item there are queries of the Where, What, When type. For example, "What several sorts of wormes in Ireland, what harme done by them, and how they are destroyed?". This was an early form of questionnaire inviting collective responses. ${ }^{91}$ However, the items were not held together even by the general Heads suggested by Bacon for natural histories. Somewhat similar lists of queries were drawn up for the Royal Society, although Boyle's "General Heads for a Natural History" did recommend larger categories - Heavens, Air, Water and Earth — encompassing more specific questions. ${ }^{92}$ One problem was that such requests for information invariably elicited the marvellous and curious rather than different versions of the common, or ordinary, phenomena 
that Bacon requested. ${ }^{93}$ Another was the difficulty of agreement on the interpretation of Heads. The transfer of commonplacing from texts to nature, and from individuals to groups, was not an easy one..$^{94}$

Some of these issues are on display in Boyle's General history of the air, published in 1692, after his death. ${ }^{95}$ Acting as literary executor, Locke saw it through the press, and did not disguise the frustration he felt in editing Boyle's messy papers. ${ }^{96}$ This reaction flowed over into his "Advertisement of the publisher to the reader" in which he indicated that the work was imperfect on several scores: Boyle's "Expectation of Assistance" had not been fulfilled, and some details of the provenance of the various contributions had been mislaid. Indeed, in his preface, Boyle admitted that he had lacked the "leisure to methodize my incoherent Notes". Nevertheless, he regarded the "Titles" of the collection as "a kind of Common Places, what my Memory, or some old Notes about divers things relating to the Air, and especially to the Causes and Effects of its Changes, supply me with in reference to that Body". ${ }^{97}$ Locke seized on this confession as an opportunity to underline a moral lesson about note taking: "Nor could it be hoped that the Authors own Memory (were he in a State of Health fit to be troubled with it) should after so long a time as this Collection has been making, and in that Variety of Men and Books he has had to do with, be able to retrieve them." 98

This project probably started in the 1660s, and Locke himself had, along with others, responded to Boyle's original set of topics and queries, arranged under Heads or "Titles". Locke's weather "Register" at Oxford from 24 June 1666 until 30 June 1683, which he kept in one of his commonplace books, is included. ${ }^{99}$ Boyle also indicated that he collated some of his own contributions from his notebooks. When discussing the effect of different combinations of salts on the temperature of fluids, he writes: "The clearest Instance I found of this Observation was afforded me by an Experiment made with the Solutions of Album and Nitre; a Relation of which I find among my Adversaria"; or elsewhere, "This is the Account my Note-Book contains of this Trial". ${ }^{100}$ In addition, the references to the participation of other observers - travellers, virtuosi, and even royalty (the Duke of York, in Titles XX and XLVI) - mark it as a collaborative project of the Baconian kind, and perhaps one that posed Bacon's own warning about delegated note taking. In his preface, Boyle says that to guide the work of the participants "I drew up a set of Heads and Inquiries of that sort, which ..., tho' purposely set down without any anxious Method, were comprehensive enough to have a good Number and Variety of Particulars conveniently referr'd to them". ${ }^{101}$ There are forty-eight of these. Several Titles have no observations: they wait as blank spaces to be filled in by subsequent observers. This is true not only of the last two, which are in effect calls for future additions; even Title III ("Of the Aether in the Atmosphere") is disturbingly empty. ${ }^{102}$

In his "Advertisement", Locke explained that Boyle had set out guidelines, albeit rather general ones: "In the first Draught he [Boyle] followed my Lord Bacon's Advice, not to be over-curious or nice in making the first Set of Heads, but to take them as they occur." Locke cautioned that for the collection to proceed with the 
involvement of many assistants, these Heads needed to be a "little more increased or methodized". Only then might Boyle's work "serve to some Men as a common Place for the History of the Air". Locke also made a significant revelation: not only that Boyle's initial Heads were very general, but that the material as now collated did not fully match the manner in which it was collected: "The Scheme of Titles under which these Materials for a History of Air are ranged, is somewhat different from that printed by him several Years since, and distributed amongst his Friends." ${ }^{103} \mathrm{He}$ was even more specific in his letter to Boyle, saying, in a postscript, "I had forgot to mention above, that I have a little altered some of your titles, the better, as I think, to accommodate them to the papers are to be ranged under them" ${ }^{104}$ We might therefore say that Locke commonplaced the various reports, assigning the material to Heads he thought most appropriate.

Sprat's perception of how things were proceeding in 1667 might well describe the results Locke saw before him in 1691. To be fair, Boyle's data were more organized than the "Preliminary Collection" — one gathered, as Sprat explained, by urging members to deliver "what came into their thoughts, or memories ... either from the observations of others, or from Books, or from their own Experience ... a mass altogether as they came". He indicated that the problem with Bacon's Histories was that they did not move beyond this initial stage, since "he seems rather to take all that comes, then to choose; and to heap, rather, then to register". This notion of a "way of Registering" was central to Sprat's claim that the Society held information "now ready in Bank", that it could be "a general Banck, and Free-port of the World". However, his summary of procedures did not suggest anything more than minimal arrangement. As he explained, "The Society has reduc'd its principal observations into one common-stock; and laid them up in publique Registers, to be nakedly transmitted to the next Generation of Men; and so from them, to their Successors. And as their purpose was, to heap up a mixt Mass of Experiments, without digesting them into any perfect model: so to this end, they confin'd themselves to no order of subjects". Defending the value of such collections, Sprat argued that "if their Registers had been more Methodical" such premature ordering would be counter-productive. ${ }^{105}$ As critics contended, this sounded more like a fulfillment of Bacon's fears about a miscellaneous "heap" of information than a repository from which items might be reliably retrieved.

\section{"NOTES OF THINGS"}

There was however, another, more optimistic view: namely, that a systematic and agreed classification of nature would assist both the collection of data, and memory. As he was supervising Sprat's History in his role as a Secretary of the Royal Society, Wilkins was at work on his universal language project, eventually published as Essay towards a real character, and a philosophical language (1668). He proposed to comprehend the world under " 40 common Heads or Genus's", together with their subdivisions into "Differences" and "Species", following Aristotle. ${ }^{106} \mathrm{He}$ set out his "enumeration of things and notions" in "Tables" designed to indicate "both the 
General and the Particular head under which it is placed" ${ }^{107}$ I suggest that we view Wilkins's scheme as potentially sponsoring a large public commonplace book, one that codified agreement on the main, common Heads, thereby responding, at least in principle, to the problem of idiosyncratic choice of categories that threatened collaborative endeavours. In order to understand how his thought (and that of other universal language projectors) connects with the theme of memory and notebooks, we need to return to Bacon.

In the Advancement of learning, Bacon treated what he called the four "Arts intellectual": invention, judgement, retention, and delivery. Memory was the third of these, or the "Art of custody"; the fourth was the "Art of elocution or tradition", which included speech, grammar, and writing. ${ }^{108}$ This last art referred back to memory, and indeed to the previous three arts since, as Bacon explained, this "Art of transmission" sought to express "to others those things which have been invented, judged, and laid up in the memory". ${ }^{109}$ This was the section (in both the Advancement and De augmentis) in which Bacon mentioned "real characters", citing the Chinese characters that "express neither letters not words in gross, but Things or Notions". Generalizing from this case, he urged further consideration of what he called "Notes of things" — artificially designed symbols that represented primitive notions; he contrasted these with "Hieroglyphics and gestures" which mirror, in some way, the notions they signify. ${ }^{110}$ The implication, hinted at by Bacon, and explored by his followers, was that such a scheme of real characters, supported by communal agreement, could transmit knowledge held in memory, perhaps more efficiently than natural languages. ${ }^{111}$ Wilkins's additional hope was that such characters might be framed to reflect "the Natural notion of things" as disclosed by "a just Enumeration and description". This is how he put it:

But now if these Marks or Notes could be so contrived, as to have such a dependance upon, and relation to, one another, as might be suitable to the nature of things and notions which they represented.... Besides, the best way of helping the Memory by natural Method, the Understanding would be highly improved. ${ }^{112}$

In this way, Wilkins sought to embody a classification of the world in the nomenclature of an artificial language, thus making it a "philosophical" one. ${ }^{113}$

One ubiquitous criticism of the feasibility of a universal language was that it imposed an intolerable burden on memory. How could individuals learn the large number of new characters? In responding, Wilkins (and other advocates of these schemes) asserted that one advantage of a universal character was that it would reduce "that great part of our time which is now required to the Learning of Words". ${ }^{114} \mathrm{He}$ quantified this, estimating that 3000 words were required for communication in his real character, and that by virtue of their methodical order they were "more easily learned and remembred than a thousand words otherwise disposed of". Having suggested that basic proficiency in Latin was "equal to the pains of Learning forty thousand words", he concluded that his language was forty times easier to acquire, so that a person of "a good Capacity and Memory" might master either the "Character 
or Language" in a month. ${ }^{115}$ This confidence rested on the fact that words or signs in this artificial language were designed to carry not only a reference to a thing or idea, but also to convey relationships, such as similarity, opposition etc. This is why Francis Lodwick, one of Wilkins's predecessors, boasted that his "real caracter" was more efficient than natural languages:

And for the dictionary, when we shall have enumerated things and rationally subordinated them, and thereby much diminished the number of needful carracters, what shall hinder but that such a dictionary ... shall much lesse burthen memory and make this carracter much easier than the ordinary dictionaryes; for things that lye disparted in a confused manner seeme more then when they are arranged [in] order, for order is the great support of memory. ${ }^{116}$

Early proponents of a universal language specifically mentioned memory overload in natural history as one of the problems addressed by such an invention. Cyprian Kinner, an associate of Comenius and a correspondent of Hartlib, made this issue his starting point. ${ }^{117}$ In a letter to Hartlib of 27 June 1647, he spoke of the difficulty of remembering the huge number of details about the qualities of plants: "Can any botanist alive, whatever his training, keep in mind the nature and powers of all plants?" 118 Kinner thought not; and he called for a new botanical terminology that captured the qualities and powers of plants, herbs etc. Combinations of consonants and vowels in syllables would indicate these common and differentiated natures, so that "a symbol made on this plan would be more than merely a new name for a plant, for to remember such a term would be to possess a compendium of the plant's powers and uses". ${ }^{119}$

This concern with mnemonic aids in universal languages demanded a focus on the essential or primary qualities of things. Here I think we are entitled to draw a connection with the somewhat similar preoccupation about distilling knowledge to essentials, or simple elements, as seen in the members of Hartlib's circle. ${ }^{120}$ For example, Ward, who advised Wilkins during the preparation of his Essay, made a link between the "Universal character" and the economy provided by the use of symbols in mathematics. By adopting symbols (as favoured by Thomas Harriot, Descartes and others) Ward reported that "not only the substance of those vast Volumes [of ancient and other writings] might be brought into the compasse of a sheet or two, but that the things thus reduced were more comprehensible and manageable; the labour of the braine much taken off". ${ }^{121}$ Hartlib, Petty, John Dury, and John Pell were enthusiastic about the possibility of reducing available knowledge to manageable units, under Heads - both as one way of committing essentials to memory, and also as the basis for new discoveries. Petty requested that "the Artificial Memory be thought upon; and, if the Precepts thereof be not too far above Children's capacities, we conceive it not improper for them to learn that also". ${ }^{122}$ It is not clear whether he meant classical "topical" memory; but one of his recommendations implies that whatever external memory prompts were used, these would need to be public, and not based on merely personal mental associations: "The most 
artificial Indices, Tables, or other Helps for the ready Finding, Remembering, and well Understanding all Things contained in these Books, must be contrived and put in Practice." ${ }^{123}$ In this thinking there is a juxtaposition of two seemingly incompatible assumptions: a call for collections of copious information and the conviction that memory can master this material. However, the members of Hartlib's circle did not perceive such dissonance; they sought to condense knowledge into a form that could be entrusted to memory, unaided by books.

John Pell's An idea of mathematicks, printed as a folio broadsheet in 1638, provided one example of how knowledge might be cast into a nutshell, or a pocketbook. ${ }^{124} \mathrm{In}$ October 1639, Theodore Haak, a friend of Hartlib, sent Pell's Idea to several people, including Marin Mersenne and Descartes. ${ }^{125}$ The English version appeared as an appendix in Dury's The reformed librarie-keeper (1650) and again in the second edition of 1651. In February 1681/2, Hooke published the Latin version, together with comments from Mersenne and Descartes, in the Philosophical collections. ${ }^{126}$

In arguing for a number of aids to the study of mathematics, Pell assumed the desirability of pithy reductions of materials to essentials. The prospects for such a task were good, at least in principle because, as Bacon had observed, "there is a great difference in delivery of the Mathematics, which are the most abstracted of knowledges, and Policy, which is the most immersed". ${ }^{127}$ Nevertheless, Pell complained that mathematics suffered similar problems to other subjects: it, too, was drowning in "that multitude of bookes, with which the world is now pestered". His response was to offer various "meanes" or aids for both the student and the adept, such as a catalogue of mathematical works; advice on "the best bookes" on various topics and the order of reading; "a Public Library, containing all those bookes, and one instrument of every sort that hath been invented". ${ }^{128}$ In addition, he proposed the publication of three new works: Pandectae mathematicae (a compendium); Comes mathematicus (a companion, perhaps a vademecum or pocketbook), and Mathematicus $\alpha \cup \tau \alpha \rho \kappa \eta \varsigma$ (roughly, a self-help manual). Having outlined the rudiments of his Idea, constituting an encyclopaedia of mathematics, Pell stated that "I see not why it might not be performed by one man, without any assistants, provided that he were neither distracted ... nor diverted". ${ }^{29}$

Pell's references to a "Pocket-booke" are significant. ${ }^{130}$ His aim of fitting "the usefullest Tables" and "Precepts" into one small notebook, as "briefly as may be", was a key part of a desire to "be no longer tyed to bookes". As he explained, the point of his various "meanes" was that a mathematician "utterly destitute of bookes and instruments" might solve any problem "exactly as if he had a complete Library by him". Even the suggested Pandectae, already summarizing other texts, might be further distilled by individuals: "men would easily see how to contract these Pandects into a pocket-booke for their ordinary use." In turn, these notebooks would allow the user to "lay them up in their heads, so as to need no booke at all". Pell admitted that such a goal "will perhaps seem utterly impossible to most", but asked that the whole repertoire of external aids be seen as acting in consort to "fortifie the imagination, to prompt the memory, to regulate our reason". ${ }^{131}$ The point here was that the notebooks 
and tables were not simply convenient records for retrieval, when required, but rather prompts for what should be committed to memory.

The reactions of Mersenne and Descartes to Pell's Idea are instructive. Both endorsed his aim of reducing knowledge into shorter, more convenient, forms. Indeed, Mersenne thought Pell had not gone far enough, telling Haak that rather than a summary of all available mathematical books, there should be a more rigorous selection of "the best and most worthy". On this method, "all pure and mixed mathematics could be included in these twelve volumes". ${ }^{132}$ In a response of 8 February 1640, Descartes welcomed the goal of collecting "in one book" all the mathematical knowledge "now scattered in many volumes". However, when it came to Pell's fundamental conviction about what should be retained in memory, Descartes dissented. Although agreeing with Pell's notion of a "self-sufficient" mathematician, he did not envisage this as non-reliance on books. When speaking of the various printed sources suggested by Pell, Descartes imagined the user consulting these, identifying various passages "should they be useful to him at any stage". He went on to express a position that broke radically with the deference to memory, as manifested in the comments of Petty, Pell, and others. As Descartes told Cornelis van Hogelande:

There are indeed many matters which are much better kept in books than memorized, such as astronomical observations, tables, rules, theorems, and in short whatever does not stick spontaneously in the memory at the first encounter. For the fewer items we fill our memory with, the sharper we will keep our native intelligence for increasing our knowledge. ${ }^{133}$

Descartes contrasted memory to reason, or understanding. External aids, such as notebooks, relieved the load on memory, enabling reason to work more freely. This was the message in several sections of his Regulae ad directionem ingenii, written in stages between 1619 and 1628 but not published until after his death. ${ }^{134}$ In this work, Descartes warned that the sluggishness of memory hampered the work of reason in long rational deductions. Consequently, he advised, there was a need to store the results of intermediate steps in a long chain of reasoning:

It seems that memory has been ordained by nature for this very purpose. But because memory is often unreliable, and in order not to have to squander one jot of our attention on refreshing it while engaged with other thoughts, human ingenuity has given us that happy invention - the practice of writing. Relying on this as an aid, we shall leave absolutely nothing to memory but put down on paper whatever we have to retain. ${ }^{135}$

The projectors of universal languages did not know of Descartes's Regulae, nor were they explicitly addressing his concern about long deductive chains of reasoning; but they did believe that their schemes compensated for the limited capacity of memory. ${ }^{136}$ For Wilkins, the work of memory was, in principle, assisted by the logical arrangements of things, ideas and words (or signs) so that the opposition or strain between memory and reason was attenuated. The full explication of "Tables" occupied 266 pages of Wilkins's Essay; but he also produced a portable fold-out 
sheet intended as a memory prompt, or as he said, "for the better help of the memory in cases of doubt or forgetfulness". This sheet helped in the task of memorizing the forty genera and the "differences". In turn, understanding the principles by which these higher levels of classification were ordered would "much facilitate the fixing of them in the memory". ${ }^{137}$ More general than Pell's mathematical pocketbooks, this sheet could be carried around as an aide-mémoire serving as a microcosm of the world. Andrew Paschall told Aubrey that his revision of Wilkins's forty genera could be presented in a pocket commonplace book. ${ }^{138}$ In reporting this to Ray, who had advised Wilkins on the taxonomy of plants, Aubrey wrote about "some Tables that might be made according to those of yours in the Bishop's Essay, and fitted to be hung up in Garden-Houses in the Manner of Maps, ... they might become a fine Ornament in Summer-Houses, and very useful for those who delight in that kind of Knowledge.... The same may also be put into a little Pocket-Book, which may be of Use where the larger Tables cannot be had". ${ }^{139}$

Wilkins was candid about the foundation of this scheme: it all rested on "the Theory it self, upon which such a design were to be founded, should be exactly suited to the nature of things" ${ }^{140}$ To be successful it had to include an adequate classification of the natural world. In his scheme, the plant and animal kingdom are covered under nine genera, from "leaf" (no. 10) to "Beast" (no. 18). In 1666, while preparing his work, Wilkins asked Francis Willughby's help "for the regular Enumeration and defining of the Families of Plants and Animals", and hoped that Willughby might "procure Mr. Ray's Company to join in it". ${ }^{141}$ As several scholars have shown, Ray did indeed assist, providing a detailed taxonomy for the botanical and zoological genera, striving to align his understanding of natural history with the logical requirements of Wilkins's divisions. ${ }^{142}$ In voicing his reluctance, Ray told Martin Lister that "In arranging the Tables I was not allowed to follow the lead of nature, but was required to fit the plants to the author's own system. I had to divide herbs into three squadrons or kinds as nearly equal as possible. I had to divide each squadron into nine lesser kinds of 'differences'.... How could anyone even hope that a method of this sort would be satisfactory, and not transparently absurd and imperfect?"143 These specifications about the number of divisions, along with Wilkins's instruction to join species "together by pairs", were made with a view to their mnemonic value, or "for the better helping of the Memory" ${ }^{144}$ Thus despite his hope that brevity and methodical order would serve memory and reason, Wilkins's attempt was sunk by the particularity of natural history.

In addition, there was the collision between the Aristotelian essentialism that informed Wilkins's nomenclature and the corpuscularianism of Boyle and Locke. This later doctrine was involved in Locke's distinction between real and nominal essences, and hence his views on substances and species. ${ }^{145}$ Given the account of a world made up of invisible particles that combined and recombined in various ways to produce both animate and inanimate things, there could be no secure knowledge of underlying substructures, and thus no sure way of distinguishing between essences and accidents - as Wilkins's scheme required. In his Essay concerning 
human understanding (1690), Locke conjectured that "There is not so contemptible a Plant or Animal, that does not confound the most inlarged Understanding". ${ }^{146}$ His caution about universals derived from similar doubts regarding our ability to know the essences of things. This in turn coloured his castigation of those who "attempt the perfect Reforming the Languages of the world ... to require that Men should use their words constantly in the same sense, and for none but determined and uniform Ideas, [as if] all Men should have the same Notions". ${ }^{147}$ Phillip Sloan has suggested that Ray may have welcomed Locke's account as a philosophical rationale for a position he was already trying to clarify. ${ }^{148}$ Ray was worried that Wilkins's supposedly "common" categories would restrict an adequate evaluation of the radically novel features of nature being gathered by observers. Ray found 558 species of plants in Cambridgeshire alone; and in his Wisdom of God (1691) announced that "the Number of corporeal Creatures is unmeasureably great, and known only to the Creator himself". On this basis, there were many species of both plants and animal yet to be found. ${ }^{149}$ Was it prudent to build a universal classification with so much new knowledge still to be sought? To be sure, the Heads outlined by Wilkins did not prevent the collection of new information on the members of any class, and he encouraged such empirical inquiry. Yet the fixed categories of the scheme did not suit an open-ended inquiry that might subsequently require reclassification, such as that of whales from fish to mammals. ${ }^{150}$

This parting of the ways between Ray's natural history and Wilkins's universal language, incorporating an externalized memory, offers a symbolic dénouement. However, the figure who best embodies the relationship between memory and notebooks is Hooke. He was perturbed by the demands on memory, and its weakness. He kept a diary. He remained a strong supporter of Wilkins, affirming in 1676 that the Bishop had designed "a Character and Language perfectly free from all manner of ambiguity, and yet the most copious, expressive and significative of any thing or Notion imaginable ... the most easie to be understood and learnt in the World". ${ }^{151} \mathrm{He}$ hoped that some kind of philosophical analysis, and recombination, of simple notions would assist both memory and reason. He interpreted natural history in the widest Baconian sense as the collection of empirical histories for all features of the world, a project that demanded the careful storage and retrieval of information.

\section{ROBERT HOOKE: MEMORY, REASON AND ARCHIVES}

Hooke was preoccupied with memory throughout his life. The weakness and fragility of this faculty concerned him, and he kept a diary (from 10 March 1671/2) partly in the hope that the act of entering notes would improve his own memory. ${ }^{152}$ One of the early entries records his purchase of a "book of mnemonic verses". ${ }^{153}$ We know that he regularly subjected his body to various chemicals and medicines, and so it is not surprising that he also looked to these as a means of enhancing memory. ${ }^{154}$ His friend, Aubrey, worked this obsession with memory into a character portrait: "As he [Hooke] is of prodigious inventive head, so [he] is a person of great vertue and goodnes. Now when I have sayd his Inventive faculty is so great, you cannot imagine 
his Memory to be excellent, for they are like two Bucketts, as one goes up, the other goes downe." 155 Hooke acknowledged this opposition as being epitomized in "the almost Proverbial Saying, that good Wits have ill Memories". ${ }^{156}$ As mentioned earlier, Huarte had popularized a medical account of this contrast. By the close of the seventeenth century, this dichotomy was being glossed through Cartesian accounts of memory. In L'homme (1630s), Descartes speculated that sensations are registered in the porous matter of the brain as impressions; these in turn encourage the flow of animal spirits along such traces, creating a disposition for later reactivation, or recall to memory. ${ }^{157}$ In exploiting this notion, The polite gentleman; or, reflections upon the several kinds of wit (1700), a French work translated by Henry Barker, delivered a jolt to any unqualified praise of extraordinary memory: "If some Men be so Stupid as to forget every Thing, there are others no less Stupid, for retaining all they read or hear." 158 After citing the adage that "a good memory and sound Judgment" are seldom combined, the author explained that in persons with good memories the "Animal Spirits" were very active, quickly laying down strong traces of impressions of ideas and enabling these to be recalled "in the same Order that the Impressions imprinted in the Brain preserve". But a memory of this power took undue precedence over reason, so that an individual possessing such a capacity would be unable "to banish from his Mind a mighty Number of Ideas it crowds in upon him". This was the predicament of those who "have taken more Care to cultivate their memories than their Minds". ${ }^{159}$ As Aubrey suggested, this contrast between memory and reason was part of Hooke's self-analysis; but it is important to recognize that it was also a matter of methodology. In his Regulae, Descartes was not so much concerned with the balance of these two faculties in individual minds, as with the need for memory to be supported by external aids so that mental effort could be channelled towards the reason and understanding. Hooke displayed a similar preoccupation.

Hooke's views on memory have been discussed by a number of scholars. ${ }^{160}$ Most notably, Lotte Mulligan has emphasized the role of his diary as a memory prompt, and as an exemplar for some of his methodological prescriptions for both natural history and natural philosophy. ${ }^{161}$ While acknowledging her important contribution, what I need to say here can be introduced by indicating a different emphasis. Whereas Mulligan stresses Hooke's desire to improve his memory, I want to concentrate on his interest in setting up external repositories in which information could be stored and ordered for subsequent retrieval. Hooke's own account of the physical basis of memory led him to think more about the necessity of external supports. It is possible that he believed that some agreed classification of knowledge, as required by a philosophical language, might sustain a kind of externalized memory. However, I think that the weight, and implications, of his remarks come down on the side of well organized, but flexible, repositories of written material. Hooke is a figure who shifts, albeit reluctantly, from a position in which notebooks are aids to memory to one in which they do the work of memory so that reason can perform more effectively.

Hooke considered the role of memory in scientific methodology in two of his major works - in the Preface to the Micrographia (1665) and in his "General scheme" 
(c. 1665-66), published after his death. ${ }^{162}$ In the Micrographia, he contemplated enlarging "the dominion, of the Senses" artificially so as to "recover some degree of those former perfections" enjoyed by Adam. ${ }^{163}$ However, he was clear that the enhancement offered by instruments, such as the microscope, must be supplemented by an intellectual reformation that extended to the higher faculties: "So many are the links, upon which true Philosophy depends, of which, if any one be loose, or weak, the whole chain is in danger of being dissolv'd; it is to begin with the Hands and Eyes, and to proceed on through the Memory, to be continued by the Reason." ${ }^{164} \mathrm{He}$ recognized that memory posed special challenges: whereas various instruments, or drugs, might magnify the input of the five senses, the role of memory was to retain information from all the senses. The capacity of memory was limited, thus requiring selective retention, and yet it often preserved useless "things":

The like frailties are to be found in the Memory; we often let many things slip away from us, which deserve to be retain'd; and of those which we treasure up, a great part is either frivolous or false; and if good, and substantial, either in tract of time obliterated, or at best so overwhelmed and buried under more frothy notions, that when there is need of them, they are in vain sought for. ${ }^{165}$

Given this diagnosis, memory appeared as the trouble spot in Hooke's quest for a way of "rectifying the operations of the Sense, the Memory, and Reason". As he said,

The next remedies in this universal cure of the Mind are to be applied to the Memory, and they are to consist of such directions as may inform us, what things are best to be stor'd up for our purpose, and which is the best way of disposing them, that they may not only be kept in safety, but ready and convenient, to be at any time produce'd for use, as occasion shall require. ${ }^{166}$

Hooke was talking not about a means of effecting some lasting improvement of natural memory, but rather about a way of ensuring that it makes the most of external data. The methodological task was to "dispose of the bank which is laid up in the Memory". ${ }^{167}$ He believed that information recorded on paper could be disposed in a manner that profiled the essential elements, thus facilitating committal to memory. Hooke accepted the standard view that visual images made strong sense impressions, thus increasing their retention in memory. In writing a preface for Moses Pitt's The English atlas (1680), he praised the good proportions of the maps as a "true Representation of the Universe and its parts", and he continued: "It may also the more easily imprint the Idea the deeper in the Memory which is the principal use of such a Work. There being nothing more conducive to the assistance of the understanding and the memory than a plain simple, clear and uncompounded representation of the Object to the senses." ${ }^{168}$ Hooke extended this principle to other kinds of data. Thus in his "Method for making a history of the weather", he proposed a display of records such that those of "a whole Moneth, may at one view be presented to the Eye", a feature achieved by the sample chart he provided. ${ }^{169}$ There is a similar attention to visual aids in his table showing the key parts of "Hydrography", arranged in Ramist fashion, with heavy, eye-catching inking of the key terms. ${ }^{170}$ This might be one instance of 
his proposal that "the Histories belonging to any one Inquiry may be placed so as to appear all at one View". ${ }^{171}$ The examples just cited — maps, charts and tables — relied on the imprinting of a visual image; but he also considered the reduction of other written information, including discursive argument, into a form more easily held in memory. In his "General scheme" he called for the equivalent of "some very good Short-hand or Abbreviation, whereby the whole History may be contracted into as little Space as is possible; for this, as I shall more fully explain in my second part, is of huge Use in the Prosecution of Ratiocination and Inquiry, and is a vast Help to the Understanding and Memory, as in Geometrical Algebra, the expressing of many and very perplex Quantities by a few obvious and plain Symbols". ${ }^{172}$ This is a reference to what he called "Philosophical Algebra" — his tantalizing, but undelivered, innovation for a general art of reasoning not limited to mathematics. ${ }^{173}$

In the "General scheme", Hooke offered an account of how we acquire knowledge in this life - via the senses, memory, and reason. The senses were imperfect but might be enhanced; however, the memory was "shallow and infirm, and so is very prone to forget many Circumstances, besides it cannot so well propound all it does remember, to be examin'd at once by the Judgment". This crucial cooperation between memory and reason was hindered by their unequal power in many individuals, as epitomized in the proverbial adages. ${ }^{174}$ Given this scenario, Hooke called for some "Method or Engine" to guide the best use of mental faculties, asserting that "no Man except the incomparable Verulam" had contributed anything helpful. Indicating that Bacon had not been able "to compleat" this "Method", he suggested that the missing tool for all "Natural Inquiry" might "not improperly be call'd a Philosophical Algebra, or an Art of directing the Mind in the search after Philosophical Truths". ${ }^{175} \mathrm{He}$ sought the best way of moving from natural history to natural philosophy. The former involved a method of "registering and ranging ... Particulars"; the latter aimed to discover causes, perhaps even "the raising of Axioms". It is likely that the "Philosophical Algebra" was meant to come into play in the second phase, reserved by Descartes for the work of reason. Nevertheless, Hooke affirmed that this "algebra" would also assist memory: "The Business [of memory] ... being nothing else but a faithful Preservation of the things committed to it, and a ready recollecting them when necessary, will be rectified and perfected by the Method of the Philosophick Algebra, and the rectifying and perfecting of the Reason, we shall refer to another Opportunity." 176

Like Bacon, Hooke stressed that the first stage of inquiry had to be a "Philosophical History" yielding a "Repository of Materials ... ranged in a convenient Order". ${ }^{177}$ The faculty responsible for retaining this material was memory, which had been routinely described as a well-ordered "repository" in writings on the art of memory. Hooke's prescriptions, however, indicate that traditional techniques had to be supplemented. ${ }^{178}$ It is worth quoting a passage following his declaration that, in his method, the various faculties are not left "without their Armour, Engines, and Assistants". Thus

the Senses are helped by Instruments, Experiments, and comparative Collections, the Memory by writing and entering all things, ranged in the best and most Natural Order; so as not only to make them material and sensible, but impossible 
to be lost, forgot, or omitted, the Ratiocination is helped first, by being left alone and undisturbed to it self, having all the Intention of the Mind bent wholly to its Work, without being any other ways at the same time imployed in the Drudgery and Slavery of the Memory, either in calling particular things to Memory, or ranging them in Order, or remembring such things as belong to another Head, or in transposing, jumbling, ranging, methodizing, and the like; for first all things are set down in their Order.... ${ }^{179}$

What did Hooke mean by the "most Natural Order"? How does memory maintain this order of material and deliver it, as required, to the reason? It is plausible that he was alluding to the potential role of an artificial scheme, such as Wilkins's philosophical language, in which the nomenclature mirrored an underlying classification. Hooke made it clear to Leibniz that the attraction of a universal character went beyond its prospects as a "supplement for Latine": not only might it be "usefull for Expressing \& Remembring of things and notions but to Direct Regulate assist and even necessitate \& compel the mind to find out and comprehend whatsoever is knowable". ${ }^{180}$ The taxonomy on which such a scheme was predicated would supply the main Heads under which the memory could deposit material as it was collected; the load on natural memory would be alleviated by the existence of such a printed framework - a memory aid along the lines of Wilkins's fold-out sheet, or Paschall's pocket-book. In true Baconian fashion, Hooke proposed that information be collected under "particular Heads of Inquiry", themselves subsumed under the two broad categories of caelestial and terrestrial phenomena. ${ }^{181}$ In principle, these could indeed be derived from an agreed classification that also served as an external memory. On this scenario, Hooke's methodology avoided the competing demands of memory and reason; it alleviated some of the work of memory by allowing it to assume and incorporate a framework of Heads. If memorized, this could function as a kind of mental wallpaper; otherwise, an external version could act as a prompt, on a larger scale than Pell's mathematical notebooks.

I think there may have been a point at which Hooke acknowledged that memory, however aided by external prompts, was inadequate to the tasks demanded by a Baconian scientific inquiry. We need to consider, side by side, what he said about the workings of memory and the method of collecting and arranging data. About fifteen years after the Micrographia and the "General scheme", Hooke speculated about the physical basis of memory in ways that had implications for his earlier methodological reflections. As part of his Cutlerian lectures at Gresham College, Hooke discussed the concept of "Light". ${ }^{182}$ In these lectures, he offered an hypothesis (partly indebted to Descartes) about how ideas were stored as material impressions in the brain. ${ }^{183}$ The two issues that preoccupied him were the load on memory and the order in which it stored material. The first concern prompted him to calculate the number of "Ideas" held in the memory of an average person over a year, deducting time asleep, when no Ideas are registered. His first estimate suggested that we add to this "Store" by "about one Million of Ideas" each year, but he scaled this down to "one hundred for every Day", so that a person would gather almost two million 
ideas over fifty years. ${ }^{184}$ In either case, the result was shocking. Regarding the order in which these ideas were stored, Hooke maintained that the "Organ of memory receives ideas in temporal order, linked to one another and so forming a "Chain of Ideas coyled up in the Repository of the Brain". ${ }^{185}$ Each idea carried its content and a marker of its position in the chain of ideas, "disposed in some regular Order; which Order I conceive to be principally that according to which they are formed". That is, this chain was laid down in chronological order; it did not mirror the true patterns in nature. ${ }^{186}$ Ultimately, in the search for these patterns, or laws, Hooke probably hoped that we might discern simple notions that could be manipulated by a "Philosophick Algebra". ${ }^{187}$ But the preparatory work involved detailed collection of data too dense, too circumstantial, to be handled by memory, even if supported by an artificial system of categories.

The challenge, as Hooke saw it, was to reorder ideas held in memory. This demanded the use of external records, for two reasons: first, because the mind could not retain the details required by a proper natural history; and second, because these records had to be amenable to frequent resorting. On the first point, Hooke acknowledged that the scale of data far exceeded the capacity of individual memory. Even the number of Heads themselves, not to mention their contents, would require the feats of a Seneca. Hooke predicted that for the history of "Air" alone there would be "a multitude of heads". ${ }^{188}$ In spite of his call, echoing Bacon, for brevitas wherever possible, this ideal was strained by the copia of data that Hooke envisaged. As far as existing knowledge was concerned, he counselled against the anxieties provoked by the many "Volumes" to be checked, declaring that "the whole Mass of Natural History, may be contain'd in much fewer Words than the writings of divers single Authors". ${ }^{189}$ However, in the collection of new material brevity was harder to achieve. Hooke castigated "all kinds of Rhetorical Flourishes", advocated conciseness in description, such as that delivered by "some very good Short-hand or Abbreviation", and suggested that instead of registering all experiments "such ought to be chosen and pick'd which are as it were the Epitomy of the rest". ${ }^{190}$ Yet this preference was countered by his stress on the importance of recording the details of "Observations or Circumstances" immediately, "because of the Frailty of Memory, and the great Significancy there may be in some of the meanest and smallest Circumstances". ${ }^{191}$ The ensuing tension is apparent in his directions for the collection of "Materials": "Care ought to be taken that they are sound and good, and cleans'd and freed from all those things which are superfluous and insignificant to the Great design; for those things do nothing but help to fill the Repository, yet notwithstanding, Brevity is not so much to be studied, as to omit many little Circumstances." ${ }^{192}$ Like Bacon, Hooke wanted the best of both worlds.

The second reason for external records was the need for a degree of flexibility not available to natural memory. Even if information might be condensed and abbreviated, Hooke stressed that it needed to be resorted. The set of Heads under which work might begin were intended to be tentative: "The Method of Distributing the Matter of Philosophical History ... need not be very nice or curious, they 
being in them laid up only in Heaps as it were, as in a Granary or Store-House; from thence afterwards to be transcrib'd, fitted, ordered and rang'd, and Tabled." 193 Hooke was adamant that the Heads would need revision as further "Observations and Experiments" superseded earlier material, but he was reluctant to discard anything prematurely; instead, it would be "good when [material] obliterated in one place, to be inscrib'd in another, where at least it may keep its place till some other much more significant to the same purpose, may give occasion to displace it". ${ }^{194}$ Unlike Descartes in the Regulae, Hooke did not focus on the inability of memory to handle long chains of deduction; rather, he stressed that memory was unable to reclassify and reshuffle bundles of information under various Heads. Moreover, any fixed set of Heads, whatever mnemonic value they provided, would be an impediment. For this reason, notebooks should not act simply as prompts for what might be committed to memory, such as the major taxonomic categories. Instead, their function was to provide a way of manipulating information physically so that the reason could proceed without recourse to an overtaxed memory.

In the "General scheme", Hooke was concerned with the collection of information by individuals as contributions to collaborative Baconian projects. He stressed that anyone involved in such a project had to accept that nothing of much value could "be expected from the single Endeavours of any one Man". ${ }^{195} \mathrm{He}$ also touched on this point in the Micrographia, contemplating how the medical histories kept by a physician, either in memory or in notes, might be amplified into a collective database:

If a Physician be therefore accounted the more able in his Faculty, because he has had long experience and practice, the remembrance of which, though perhaps very imperfect, does regulate all his after actions: What ought to be thought of that man, that has not only a perfect register of his own experience, but is grown old with the experience of many hundreds of years, and many thousands of men. ${ }^{196}$

Accordingly, his suggestions for note taking combined hints for both the individual and the group - the crucial point being the collation of information in an institutional archive. ${ }^{197}$

What Hooke proposed was an array of notebooks, loose slips of paper, and other devices that constituted an information network. ${ }^{198}$ It is fair to say that his stipulations were not as clear as they might have been, and his verbal descriptions might well have been enhanced by the visual aids he often advocated. I will briefly describe the elements of this network in the order that Hooke presented them, italicizing his key terms. ${ }^{199}$ First, "a very fine piece of Paper" on which to write short notes under "Schedules" (elsewhere "Schedules of history") containing "the abbreviated and complicated Histories of Observations and Experiments", perhaps along the lines of the Baconian natural histories he listed earlier in the "General scheme". Second, since these schedules are to be on single sheets of fine paper, Hooke suggests that they be stuck "with Mouth Glew" in "a large Book" bound in the manner of those used for "keeping Prints, Pictures, Drawings". He calls this book "a Repository". This procedure is meant to facilitate the process of continual sifting and resorting: 
the pieces of paper could be moved around so that information "which was plac'd first may be plac'd middle-most, or last, or transpos'd to another Head, or a little remov'd to suffer another to be interpos'd". It is not clear whether Hooke means that schedules (that is, lists of topics or inquires), or more particular observations, are to be moved in this way. His reference to placing something under a different "Head" suggests that it is lower level data. Thirdly, the "Queries" that an individual "propounds to himself" regarding a certain "History" are to be recorded in a "some other small long Book, or else better in a single Sheet of Paper". These queries could be checked against the schedules in the public "Repository", allowing for adjustment of the queries "as further Information shall give occasion". Fourth, "a small Picture of the Thing" discussed should be given, partly because a picture is more reliable and efficient than words. Fifth, Hooke anticipates that it might be helpful to add "small Schedules of particular Deductions, or Conjectures" to the larger "Schedules of history". If so, then these should be "exprest in a very few words" so as not to "disturbe the Mind"; and better still, they should be "written with an Ink of some other Colour, as Red or Green, or the like, for this will much assist the Memory and Ratiocination, as I shall after manifest more at large". Thus ends his "General scheme" — with an unfulfilled promise. Nevertheless, this storage and transfer of various notes accorded with Hooke's emphasis on the need for continual resorting of information - a process that he believed could not be accomplished by individual memory. ${ }^{200}$

Among Hooke's papers, Richard Waller found his account of the meetings of the Oxford Philosophical Society:

At these Meetings, which were about the Year 1655 (before which time I knew little of them) divers Experiments were suggested, discours'd and try'd with various successes, tho' no other account was taken of them but what particular Persons perhaps did for the help of their own Memories; so many excellent things have been lost. ${ }^{201}$

Hooke may well have pledged to guard against such losses. In this respect, he shared Sprat's emphasis on collections and registers as crucial to the status of the Royal Society as a "bank" of information. I doubt, though, that Hooke ever let himself be carried away with the anti-bookish rhetoric that inspired Sprat to predict that the new philosophy, grounded in practical, manual skills, would survive "the loss of a Library" or the "overthrowing of a Language". ${ }^{202}$

Hooke concluded that natural history, and the inferences and generalizations to be drawn from it, required the contents of many individual memories - externalized on paper, in visual displays, in repositories, libraries and museums. With such archives, material could be rearranged, breaking with the storage mechanisms of natural memory, and also with the Heads chosen for preliminary collection. In arriving at this position, Hooke was torn between the lure of being able to recall things from memory and the acceptance of retrieval of information from external sources as the norm. As I have suggested, several of his contemporaries also wrestled with this issue - one exacerbated by the large collections of empirical data required for Baconian natural histories. Some members of Hartlib's circle and the Royal Society adapted 
the methods of commonplacing to the collaborative work of gathering information. Bacon's warning about the proper selection of Heads and the difficulties of group note taking proved to be judicious. So, too, did his recognition that the balance between brevitas (for memory) and copia (in natural history) was hard to strike. In these circumstances, the reduction of knowledge to simple forms under an agreed set of Heads was attractive. For some, this was one of the appeals of Wilkins's universal language scheme: its nomenclature acted as a public memory aid, reinforcing a classification of the world that could guide research. There was, however, a strong, and ultimately triumphant, counter theme: namely, that the demands of memory and reason were in competition, and that notebooks (and other external records) must be regarded as ways of relieving memory so that reason could function more efficiently. Descartes identified this issue in his deliberations about individual minds pursuing complex trains of deduction; Hooke confronted it in the context of practical methods of note taking that could be shared by members of a Baconian community. It was Hooke, a person troubled by the weakness of his own memory, who reflected on the need for external archives as crucial for the collection and retrieval of information. This was one of the foundation moments of the achievement that Helmholtz thought his nineteenth-century contemporaries had forgotten.

\section{CONCLUSION}

The relationships I have discussed in this article - between memory, notebooks and natural history - largely unravelled during the eighteenth century. The clearest break was that between memory and natural history. In his Critica botanica (1737), Carolus Linnaeus stipulated that the natural historian must memorize all the genera, but conceded that the names of species had multiplied to an extent that put them beyond the capacity of most memories ${ }^{203}$ For Georges Louis Leclerc Buffon, some fifty years later, any association of natural history with memory was rejected outright: first, because reliance on memory was no longer an acceptable warrant for scientific evidence; second, because he dismissed "all the methods which have been compiled to aid the memory". ${ }^{204}$ This double apostasy is represented in the Encyclopédie, in spite of its adoption of Bacon's classification in the "Preliminary discourse" and its map of knowledge. In the latter, the subjects of natural history, such as botany and zoology, do not appear under "Memory" but under "Reason". In the article "Histoire" (1765), natural history is said to be "improperly called history" because it should be seen as "an essential part of physics". ${ }^{205}$ The article "Botanique" severed all connections between artificial memory aids and the structure of the natural world (as envisaged by Kinner, Wilkins and others). Individuals might well construct memory aids to help them remember botanical details, but this was a choice in which "any method will suffice". ${ }^{206}$

The nexus between memory and notebooks also changed in subtle, but profound, ways. In the seventeenth century, notebooks were often seen as prompts for knowledge the memory should retain. The English virtuosi and natural historians I have discussed - all admirers of Bacon — did not relinquish this attitude without 
a struggle. Yet although Bacon encouraged the development of aids to memory, his own programme for a copious and collaborative natural history diminished the role of memory in science. During the Enlightenment, retrieval of information from external repositories increasingly came to be seen as the norm. The preoccupation with improving or aiding individual memory was no longer sustained by strong philosophical convictions.

\section{ACKNOWLEDGEMENTS}

The research for this article was made by possible by an Australian Professorial Fellowship awarded by the Australian Research Council. For access to material in their custody, I am grateful to the Royal Society of London, the British Library, and the Keeper of Modern Western Manuscripts, Bodleian Library, Oxford. I thank the Warden and Fellows of All Souls College, Oxford for their support while I was a Visiting Fellow during 2004-05. For their helpful comments, I thank the anonymous referees and the editor of this journal.

\section{REFERENCES}

1. Hermann Helmholtz, Popular lectures on scientific subjects, transl. by E. Atkinson (London, 1873), 12.

2. Letter, John Beale to Robert Boyle, 29 September 1663, in Robert Boyle, Correspondence of Robert Boyle, ed. by Michael Hunter, Antonio Clericuzio and Lawrence M. Principe (6 vols, London, 2001), ii, 128-42, p. 133. See also "The Mnemonical probleme", British Library, Add. MSS: 4384, ff. 64-118.

3. Letter, Beale to Boyle, 29 September 1663, in Boyle, Correspondence (ref. 2), ii, quotations at pp. 131-5. The earliest known usage of "note-book" is 1579; in the early modern period, notebooks were commonly called "paper-books". See Oxford English dictionary (2nd edn, Oxford, 1989). Paperbooks have to be distinguished from tablebooks (or writing tables) which had erasable surfaces. Beale alludes to the latter, saying that we should "wipe all off, \& then engrosse what is fit to be recorded" - that is, by committing it to memory (p. 135). See Roger Chartier, Frank Mowery, Peter Stallybrass, and Heather Wolfe, "Hamlet's Tables and the technologies of writing in Renaissance England", Shakespeare quarterly, lv (2004), 379-419; and H. R. Woudhuysen, "Writing-tables and table-books", The electronic British Library journal (2004), article 3.

4. See Francis Goyet, Le sublime du "lieu commun": L'invention rhétorique dans l'Antiquité et à la Renaissance (Paris, 1996); and Ann Moss, Printed commonplace-books and the structuring of Renaissance thought (Oxford, 1996). On this preference for memorizing, see Francesco Petrarch, Petrarch's secret, transl. by W. Draper (Norwood, PA, 1977), 99-102 for Petrarch's imagined conversation with Saint Augustine.

5. Francis Bacon, De augmentis, in The works of Francis Bacon, ed. by J. Spedding, R. L. Ellis and D. Heath (14 vols, London, 1961-63), iv, 435.

6. [James Duport], "Rules to be observed by young scholars in the University" (1660), Trinity College, Cambridge, MS: O.10A.33.

7. These sermons were themselves a product of rhetorical training: tutors and fellows, usually destined for the clergy, practised by performing “commonplaces". In Samuel Clarke's, Lives of thirty-two divines (London, 1677), 115, these are defined as "a Colledg-exercise in Divinity, not different from a Sermon, but in length". Cited in Harris F. Fletcher, The intellectual development of John Milton (2 vols, Urbana, 1956-61), ii, 57. As late as 1692, the subtitle to John Ray's Wisdom of 
God manifested in the works of the creation (London, 1691) is: "Being the substance of some common Places delivered in the Chappel of Trinity College, in Cambridge". This did not appear in the 2nd edn, 1692.

8. Richard Holdsworth, "Directions for a student in the Universitie", Emmanuel College, Cambridge, MS 1.2. 27(1). This was begun in 1615 and completed after 1637. It was written out in a scribal hand for use in the college. For a description of the manuscript, bound in a notebook measuring $7 \frac{1}{2}$ by $5 \frac{3}{4}$ inches, see Fletcher, Milton (ref. 7), ii, 84-88. The quotations are taken from sections 49-51 of the "Directions", which Fletcher prints in Appendix II, ii, 623-55.

9. On this, and Boyle's mode of working, see Harriet Knight, "Organizing natural knowledge in the seventeenth century: The works of Robert Boyle", Ph.D. dissertation, University of London, 2003, esp. chaps. 2-3.

10. Letter, Beale to Boyle, 29 September 1663, in Boyle, Correspondence (ref. 2), ii, 129-30.

11. The editors of Henry Oldenburg's correspondence, in which Beale features prominently, make a blunt assessment: "He suffered from total recall and confident reliance upon an unreliable memory." See Henry Oldenburg, The correspondence of Henry Oldenburg, ed. and transl. by A. Rupert Hall and Marie Boas Hall (13 vols, Madison etc., 1965-86), i, 320-1. This may be a harsh judgement, since it is founded, in part, on Beale's errors in literary allusions and citations of sources - not unusual failings. The entry by Patrick Woodland in the Oxford dictionary of national biography is more forgiving of Beale's eccentricities.

12. Letter, Beale to Boyle, 25 February 1663, in Boyle, Correspondence (ref. 2), ii, 68-71. John Hales (1584-1656) was a humanist and Fellow at Eton.

13. Letter, Beale to Boyle, 30 July 1666, in Boyle, Correspondence (ref. 2), iii, 194-6, p. 196. For a detailed account of Beale's views and their context, see Rhodri Lewis, "The best mnemonicall expedient': John Beale's art of memory and its uses", The seventeenth century, $\mathrm{xx}$ (2005), 113-44.

14. René Descartes to Franz Burman, 16 April 1648, in The philosophical writings of Descartes, transl. by John Cottingham, Robert Stoothoff and Dugald Murdoch (3 vols, Cambridge, 1991), iii, 334.

15. Compare these features of Bacon's legacy with the more narrow focus on methodology that dominated nineteenth-century debates. See Richard Yeo, "An idol of the market-place: Baconianism in nineteenth-century Britain”, History of science, xxiii (1985), 251-98.

16. Francis Bacon, "Preparative towards a natural and experimental history", Works (ref. 5), iv, 251-70, pp. 265-70. In The advancement of learning (1605), Bacon named three kinds of natural history: "of nature in course, of nature erring or varying, and of nature altered or wrought." See Works (ref. 5), iii, 330. But he also regarded the various possible "particular histories" as natural histories. I am concerned with both "natural history" and "natural histories".

17. For the relations between Hartlib's correspondents and the Royal Society, see Charles Webster, The great instauration: Science, medicine, and reform 1626-1660 (London, 1975), passim. See also Mark Greengrass et al. (eds), Samuel Hartlib and universal Reformation (Cambridge, 1994).

18. Charles Webster, "The origins of the Royal Society", History of science, vi (1967), 106-28, p. 117.

19. Vivian Salmon, The works of Francis Lodwick: A study of his writings in the intellectual context of the seventeenth century (London, 1972), 111. For the persistence of mnemonic skills in early print society, see Keith Thomas, "Literacy in early modern England", in The written word: Literacy in transition, ed. by Gerd Baumann (Oxford, 1986), 97-131.

20. Mary Carruthers, The book of memory: A study of memory in medieval culture (Cambridge, 1990), 8.

21. W. T. Clanchy, From memory to written record in England, 1066-1307 (2nd edn, Cambridge, MA, 1993), 172-9.

22. Walter Ong, Ramus, method, and the decay of dialogue (Chicago, 2004; 1st publ. Cambridge, MA, 
1958), 306-18. Ramist diagrams, based on binary subdivisions, may have assisted compression, and hence memory, of information. I cannot treat this here. For the issue of Ramus's influence in England, see Wilbur S. Howell, Logic and rhetoric in England, 1500-1700 (Princeton, 1956), 202; and Mordechai Feingold, "English Ramism: A reinterpretation", in The influence of Petrus Ramus: Studies in sixteenth- and seventeenth-century philosophy and sciences, ed. by Mordechai Feingold, Joseph S. Freedman and Wolfgang Rother (Basel, 2001), 127-76.

23. Frances Yates, The art of memory (London, 1966), 355.

24. Paolo Rossi, Logic and the art of memory: The quest for a universal language, transl. by Stephen Clucas (2nd edn, London, 2000), p. x. First published as Clavis universalis: Arti della memoria e logica combinatoria da Lullo a Leibniz (Bologna, 1960, 1983).

25. See Ad Herennium. De ratione dicendi, with an English translation by Harry Caplan (Cambridge, MA, 1954). This anonymous work dates from about $86-82$ B.C. The title indicates that it is addressed to Gaius Herennius. This text was contemporary with the works of Cicero and mistakenly attributed to him in the thirteenth century.

26. Cornelius Agrippa, Of the vanitie and uncertaintie of the artes and sciences (London, 1569), 24-25. The original Latin version was De incertitudine et vanitate scientiarum et artium (Paris, 1531). For a less negative, but not enthusiastic, description of "locall or artificiall memory", see Gulielmus Gratarolus, The castel of memoirie (London, 1562; repr. New York, 1971), chap. 7.

27. Robert Burton, The anatomy of melancholy, ed. by Thomas C. Faulkner, Nicholas K. Kiessling, and Rhonda L. Blair (3 vols, Oxford, 1989; 1st publ. 1621), ii, 92. Even a primer on mnemonic techniques made this admission: "Writings (I confesse) are simply the most happie keepers of any thing in memorie, and doth for speed and certaintie go beyond any art of Memorie." John Willis, Art of memory (London, 1621), "To the reader", sig. A3r.

28. Thomas Fuller, The holy state (London, 1642), Book III, 174-6. See the facsimile edition, Thomas Fuller, The holy state and the profane state, ed. by Maximilian Graff Walten (2 vols, New York, 1938), i, 174-5 for his memory feats.

29. Samuel Pepys, The diary of Samuel Pepys, ed. by Robert Latham and William Matthews (11 vols, London, 1970), 22 January 1660/1, ii, 20-21; John Aubrey, Aubrey's brief lives, ed. by Oliver L. Dick (London, 1950), p. cv.

30. Juan Huarte, The examination of mens wits (London, 1594; 1st publ. in 1575), 60-63.

31. [John Wallis], "The strength of memory", Philosophical transactions, xv (1685), 1269-71.

32. Edward Gibbon, Essay on the study of literature (London, 1764; original French edn, 1761), 12.

33. Roger North, General preface and life of Dr John North, ed. by Peter Millard (Toronto, 1984), 155-6. North's life of his brother, John, was first published in 1744. Another illustration of this concern about the failing memory of great scholars is discernible in John Conduit's conversation with Newton in his 83rd year, on 7 March 1724/5, in which Conduit observed "his head clearer \& memory stronger than I had known him for some time". King's College, Cambridge, Keynes MS 130.11,1r. See also William Stukeley's memoir of Newton, Royal Society MS 142, 61r-62r. Both documents are available at www.newtonproject.imperial.ac.uk.

34. John Locke, An essay concerning human understanding, ed. by Peter H. Nidditch (Oxford, 1975), II.x.8. See also IV.i.8-9; IV.xi.11 for other notices of the crucial role of memory in knowledge.

35. John Locke, Some thoughts concerning education, ed. by John W. and Jean S. Yolton (Oxford, 1989), sections 176 and 185.

36. Francis Bacon, The advancement of learning, in Works (ref. 5), iii, 329. See also Sachiko Kusukawa, "Bacon's classification of knowledge", in The Cambridge companion to Bacon, ed. by Markku Peltonen (Cambridge, 1996), 47-74.

37. Jean le Rond d'Alembert, Preliminary discourse to the Encyclopedia of Diderot, transl. by Richard N. Schwab, with Walter E. Rex and Richard N. Schwab (Chicago, 1995), 55-56. 
38. Bacon, De augmentis, in Works (ref. 5), iv, 292-8. See also Advancement, in Works (ref. 5), iii, 329, 352-4; "A description of the intellectual globe", in Works (ref. 5), v, 503-4. For a similar account, see Burton, Melancholy (ref. 27), i, 152: "Memory, lays up all the species which the senses have brought in, and records them as a good Register, that they may be forth-coming when they are called for by Phantasie and Reason." Bacon's formulation seems to omit some of the complexities in the passage from senses via imagination and memory to cognition as found in earlier writings. See A. Mark Smith, "Picturing the mind: The representation of thought in the Middle Ages and Renaissance", Philosophical topics, xx (1992), 149-70.

39. Thomas Hobbes, Leviathan, ed. by Richard Tuck (Cambridge, 1996), chap. 9, 60. Hobbes also assigned experimentally-produced phenomena to historia, denying that they provided a basis for knowledge any sounder than testimony in natural history. See Simon Schaffer and Steven Shapin, Leviathan and the air-pump: Hobbes, Boyle, and the experimental life (Princeton, 1985), 114-15.

40. See Lorraine Daston and Katherine Park, Wonders and the order of nature 1150-1750 (New York, 2001), 220-40; Gianna Pomata and Nancy G. Siraisi (eds), Historia: Empiricism and erudition in early modern Europe (Cambridge, MA, 2005).

41. Johannes Faber, Thesaurus (Rome, 1651), 540, cited in and transl. by Silvia De Renzi, "Writing and talking of exotic animals", in Books and sciences in history, ed. by Marina Frasca-Spada and Nick Jardine (Cambridge, 2000), 151-67, p. 161. However, by 1600 many leading botanists doubted the capacity of memory to deal with the expanding number of known plants. See Brian W. Ogilvie, "The many books of nature: Renaissance naturalists and information overload", Journal of the history of ideas, 1xiv (2003), 29-40, pp. 33-35; and his The science of describing: Natural history in Renaissance Europe (Chicago and London, 2006), 181.

42. Letter, Tancred Robinson to John Ray, 18 April 1684, in John Ray, Philosophical letters between the late learned Mr Ray ... to which are added those of Francis Willughby, ed. by William Derham (London, 1718), 153-4. Robinson was knighted in 1714 and appointed physician-in-ordinary to George II. This letter (and some others) is also found in The correspondence of John Ray, ed. by Edwin Lankaster (London, 1848).

43. Letter, Ray to Robinson, 29 April 1685, Philosophical letters (ref. 42), 180-1.

44. Francis Bacon, Novum organum, in Works (ref. 5), iv, Book I, aphorisms no. 100 and 103 (pp. 95-96). Pliny the Elder, Naturalis historia, transl. by H. Rackham (10 vols, London, 1974), i, 13. See Trevor Murphy, Pliny the Elder's Natural History: The empire in the encyclopedia (Oxford, 2004).

45. Yates, Art of memory (ref. 23), 358. Having seen the classical and allegorical figures on the gallery windows in Bacon's house at Gorhambury, Aubrey remarked that "perhaps his Lordship might use them as Topiques for Locall memorie". Aubrey, Aubrey's brief lives (ref. 29), 14.

46. Jean Bodin, Method for the easy comprehension of history, transl. by Beatrice Reynolds (New York, 1966), 28. Cited in Ann Blair, The theatre of nature: Jean Bodin and Renaissance science (Princeton, 1997), 68.

47. Bacon, Novum organum, Book I, aphorism 101, in Works (ref. 5), iv, 96. Compare the translation in The Instauratio Magna part II: Novum organum and associated texts, ed. by Graham Rees and Maria Wakely (Oxford, 2004), 159: "But even after all the abundance and matter of natural history and experience that we need is all present and correct, the intellect is still quite incapable of working on that matter unprompted and by memory: you might just as well expect to be able to calculate and get through an ephemeris by force of memory." For a similar point, see Bacon, De augmentis, in Works (ref. 5), iv, 435.

48. Bacon, Novum organum, in Works (ref. 5), iv, 96.

49. Paolo Rossi, Francis Bacon:From magic to science, transl. by Sacha Rabinovitch (Chicago, 1968), 212-13, 219. First published as Franceso Bacone: Dalla magia alla scienza (Bari, 1957). 
50. Bacon, De augmentis, in Works (ref. 5), iv, 435-7.

51. Bacon, Novum organum, in Works (ref. 5), iv, aphorism no. 125, 110-11.

52. Bacon, "Of travel", in Essays, Works (ref. 5), vi, 417-18, p. 417. See also De augmentis, "in our times journals are only used in sea-voyages and expeditions of war." Bacon, Works (ref. 5), iv, 310.

53. Bacon, De augmentis, in Works (ref. 5), iv, 310.

54. See Ephraim Chambers, Cyclopaedia (2nd edn, 2 vols, London, 1738), "Book": "Waste-Book, is the first, and most essential: in this, all kinds of matter are, as it were, mixed and jumbled together; to be afterwards separated and transferred into others." See also Mary Poovey, A history of the modern fact: Problems of knowledge in the sciences of wealth and society (Chicago, 1998), 32-33, 36-38.

55. Francis Bacon, "Comentarius solutus sive pandecta, sive ancilla memoriae", Works (ref. 5), xi, 61-62, for notebook entries of 1608; and pp. 18-25 for Spedding's descriptions of these "Private memoranda".

56. Francis Bacon, Sylva sylvarum: or, a natural history, in ten centuries, published by William Rawley (8th edn, London, 1664), “To the reader” (by Rawley). See also Bacon, Works (ref. 5), ii, 335.

57. William G. Crane, Wit and rhetoric in the Renaissance: The formal basis of the Elizabethan prose style (New York, 1937); and Karl R. Wallace, Francis Bacon on communication and rhetoric (Chapel Hill, 1943).

58. Moss, Printed common-place books (ref. 4), 117. For two very different examples, see James Howell, Instructions and directions for forreine travell (London, 1650; 1st publ. 1612), 21; Letter, G. W. Leibniz to Gabriel Wagner, 1696, in Gottfried Wilhelm Leibniz, Philosophical papers and letters, transl. and ed. by Leroy E. Loemker (Dordrecht, 1969), no. 48, 465. See also Justin Stagl, A history of curiosity: The theory of travel 1550-1800 (Chur, 1995).

59. Francis Bacon, The advancement of learning, in Works (ref. 5), iii, 398. See also Bacon, "Of discourse", in Essays, in Works (ref. 5), vi, 455-6. Bacon was critical of simplistic epitomes that evacuated useful content. Michel de Montaigne voiced his annoyance at the deficiencies of this method, although he continued to use commonplaces in his own work. See Warren Boutcher, "Montaigne's legacy", in The Cambridge companion to Montaigne, ed. by Ulrich Langer (Cambridge, 2005), 27-52.

60. Bacon, Parasceve ad historiam naturalem, in Works (ref. 5), iv, 253-7. See also Peter R. Anstey, "Locke, Bacon and natural history", Early science and medicine, vii (2002), 65-92, pp. 71-72; Ogilvie, Science of describing (ref. 41), 4-5, 258-9.

61. Baconiana; or certain genuine remains of Sir Francis Bacon (London, 1679), 47-48.

62. Rossi, Bacon (ref. 49), 213.

63. Moss, Printed common-place books (ref. 4), 271. For a supportive echo, see Thomas Sprat, History of the Royal Society (1667), ed. by Jackson I. Cope and Harold Whitmore Jones (London, 1959), 332.

64. Bacon, De augmentis, in Works (ref. 5), iv, 421. For a masterly account of Bacon's attitude to both logic and rhetoric, see Brian Vickers, "Bacon and rhetoric", in Companion to Bacon, ed. by Peltonen (ref. 36), 200-31.

65. Bacon, De augmentis, in Works (ref. 5), iv, 435.

66. Bacon, Parasceve, in Works (ref. 5), iv, 255. See Daston and Parks, Wonders and the order of nature (ref. 40), 220-31, on both Bacon's relative lack of interest in the marvellous and curious, and hence his distance from both earlier natural histories and the passion for "strange facts" displayed by some members of the Royal Society.

67. Bacon, Novum organum, Book I, aphorisms 119, 117, in Works (ref. 5), iv; Parasceve, in Works (ref. 5), iv, 255.

68. Bacon, Advancement, in Works (ref. 5), iii, 405; and "Of dispatch", in Essays (ref. 5), vi, 434-5. 
Bacon distinguished his sense of brevity from Ramus's reduction of knowledge to dichotomies presented in diagrams. See Howell, Logic and rhetoric (ref. 22), 202; Feingold, "English Ramism" (ref. 22), 171-3.

69. Lorraine Daston, "Perché i fatti sono brevi?", Quaderni storici, no. 108 (2001), 745-70: "La brevità inoltre favoriva le capacità di attenzione e memoria" (p. 757); and "Nel caso di fenomeni imprevedibili ed effimeri, la brevità inoltre coadiuvava la memoria” (p. 760).

70. Bacon, Novum organum, Book II, aphorism 26, in Works (ref. 5), iv, 162.

71. For a notice of this difference, see Adrian Johns, "Reading and experiment in the early Royal Society", in Reading, society, and politics in early modern England, ed. by K. Sharpe and S. N. Zwicker (Cambridge, 2003), 244-71, p. 247. For an account of the way this difference was negotiated, see Daston, "Perché i fatti sono brevi?" (ref. 69) and, more generally, Lorraine Daston, "Taking note(s)", Isis, cxv (2005), 443-8; also Pomata and Siraisi, Historia (ref. 40), 2-22.

72. This was one of the assumptions behind printed commonplace books, appearing from the 1500s. See Moss, Printed commonplace-books (ref. 4), chaps. 6-8.

73. Anthony Grafton and Lisa Jardine, “'Studied for action': How Gabriel Harvey read his Livy”, Past and present, cxxix (1990), 30-78. See also Kevin Sharpe, Reading revolutions: The politics of reading in early modern England (New Haven, 2000), 270-95.

74. Anthony Grafton, "Where was Salomon's house? Ecclesiastical history and the intellectual origins of Bacon's New Atlantis", in Die Europaische Gelehrtenrepublik im Zeitalter des Konfessionalismus, ed. by Herbert Jaumann (Wiesbaden, 2001), 21-38.

75. James Spedding suggested that this letter was written by Bacon on behalf of Robert Devereux, the second Earl of Essex. See Bacon, Works (ref. 5), ix, 1-26. Vernon Snow, "Francis Bacon's advice to Fulke Greville on research techniques", Huntington Library quarterly, xxiii (1960), 369-78, gives strong reasons for concluding that Bacon was the author. I cite from Snow's transcription; see p. 373; and p. 371 for Bacon's mention "of the Notes themselves, which must be natural, moral, Politick or Military".

76. Snow, "Bacon's advice" (ref. 75), 372-3. Bacon was not averse to collecting certain material "by ye labor of a servant in part". See Works (ref. 5), xi, 62. He said that "some books also may be read by deputy, and extracts made of them by others; but that would be only in the less important arguments, and the meaner sort of books". Bacon, "Of studies", in Essays, in Works (ref. 5), vi, 498.

77. Snow, "Bacon's advice" (ref. 75), 374.

78. Letter, W. Rand to Hartlib, 14 February 1652, Hartlib Papers, Sheffield University Library (CDRom, 2nd edn), 62/17/1A-2B.

79. Samuel Hartlib, "Desiderata. epitomae et analyses. autorum selectiorum". BL Sloane: MS 638 ff. 17A-23B, in Hartlib papers (ref. 78).

80. William Petty, The advice of W. P. to Mr. Samuel Hartlib, for the advancement of some particular parts of learning (1648), in The Harleian miscellany: or, a collection of scarce, curious, and entertaining tracts (London, 1845), vi, 1-13, p. 3. Aubrey, Brief lives (ref. 29), 154, 240-1, said that both Petty and Hobbes professed not to have read many books, and that this was one cause of their inventiveness.

81. Hartlib Papers, 30/4/46A-B (Ephemerides, 1640, part 2). Cited in Noel Malcolm, "Thomas Harrison and his 'Ark of studies': An episode in the history of the organisation of knowledge", The seventeenth century, xix (2004), 196-232, p. 196.

82. Cited in Robert F. Young, Comenius in England (London, 1932), 66. These comments occur in a letter from London of 8/18 October 1641 to his friends in Leszno, Poland.

83. Young, Comenius (ref. 82), 67. Comenius refers to "a learned man, N. Harisson" (p. 66).

84. Malcolm, "Thomas Harrison" (ref. 81), 205, 220-1 argues that the account of this technique in 
Vincent Placcius, De arte excerpendi (Stockholm and Hamburg, 1689) is based on Harrison. Compare Ann Blair, "Reading strategies for coping with information overload, ca. 1550-1700", Journal of the history of ideas, 1xiv (2003), 11-28, p. 20. See "Design for an index cabinet with instructions for use, by a friend of Sam. Hartlib", BL Add MSS: 41,846 ff. 194-204.

85. Young, Comenius (ref. 82), 66. See Malcolm, "Thomas Harrison" (ref. 81), 219-20, for the comparison with Leibniz.

86. Letter, Seth Ward to Sir Justinian Isham, 27 February 1751/2, printed in H. W. Robinson, "An unpublished letter of Dr Seth Ward", Notes and records of the Royal Society of London, vii (1949), 68-70, p. 69. See also Margery Purver, The Royal Society: Concept and creation (London, 1967), chap. 4. Ward became Bishop of Exeter in 1662 and of Salisbury in 1667.Wilkins was consecrated Bishop of Chester in 1668.

87. Robert Hooke, "Proposals for ye good of ye RS" [no date, but possibly early 1670s], Royal Society of London, Classified Papers, CI. P/20/50, ff. 85-98, at f. 86r. See also f. 94r for the means of attaining knowledge: "to wit in three places. first in bookes. 2 dly in men. 3dly in the things themselves". For its likely date, see Michael Hunter and Paul B. Wood, "Towards Solomon's house: Rival strategies for reforming the early Royal Society", History of science, xxiv (1986), 49-108, p. 95. Charles R. Weld, A history of the Royal Society (2 vols, London, 1848), i, 146-50, prints material from similar documents, which he attributes to Hooke. For criticism of his dating of the papers, and a correction concerning their location (in BL MS Sloane 1039 ff. 112-13), see Hunter and Wood (in this ref.), 94-95, 107 n. 211.

88. Petty, Advice (ref. 80), 3.

89. Bacon, Parasceve, in Works (ref. 5), iv, 251-2; also Anstey, "Locke, Bacon" (ref. 60), 71; Knight, "Organizing natural knowledge" (ref. 9), 44-54. Bacon distinguished here between collection and analysis, saying that "as much as relates to the work itself of the intellect, I shall be able to master that myself" (p. 251). I return to this point in my discussion of Hooke.

90. Sprat, History (ref. 63), 155-6. On the issues raised here, the locus classicus is P. B. Wood, "Methodology and apologetics: Thomas Sprat's History of the Royal Society", The British journal for the history of science, xiii (1980), 1-26. More generally, see William T. Lynch, Solomon's child: Method in the early Royal Society of London (Stanford, 2001).

91. [Samuel Hartlib], Samuel Hartlib. His legacie of husbandry (2nd edn, London, 1652), appendix. On some of the scant answers Hartlib received, see Patricia Coughlan, "Natural history and historical nature: The project for a natural history of Ireland", in Hartlib, ed. by Greengrass et al. (ref. 17), 298-319, pp. 306-7.

92. Robert Boyle, "General heads for a natural history of a countrey, great or small, imparted likewise by Mr. Boyle", Philosophical transactions, i (1665-66), 186-9. One of the first things entered in the Register Book of the Royal Society, in January 1660/1, was "Questions propounded and agreed to be sent to Teneriffe by the Lord Brouncker and Mr. Boyle". There were twenty-two questions, although, as Weld remarked, they were "rather a series of instructions". See Weld, History (ref. 87), i, 100. For a detailed account, see Michael Hunter, "Robert Boyle and the early Royal Society: A reciprocal exchange in the making of Baconian science," The British journal for the history of science, forthcoming. I thank the author for a pre-publication copy.

93. See Sprat, History (ref. 63), 158-78 where some of the questions themselves invited this; and other, neutral ones, still brought tales of wonder.

94. I cannot deal further with these issues here, but see Lorraine J. Daston, "The factual sensibility", Isis, 1xxix (1988), 452-70; Daniel Carey, "Compiling nature's history: Travellers and travel narratives in the early Royal Society", Annals of science, liv (1997), 269-92; Barbara J. Shapiro, A culture of fact: England, 1550-1720 (Ithaca and London, 2000), chaps. 3-6; and Hunter, "Boyle and the early Royal Society" (ref. 92).

95. Robert Boyle, The general history of the air, designed and begun by the Hon. Robert Boyle (London, 
1692), in The works of Robert Boyle, ed. by Michael Hunter and Edward B. Davis (14 vols, London, 1999-2000), xii, 3-159. For the context of this inquiry, see Kenneth Dewhurst, "Locke's contribution to Boyle's researches on the air and on human blood", Notes and records of the Royal Society of London, xvii (1962), 198-206; and Anstey, "Locke, Bacon" (ref. 60).

96. Letter, Locke to Boyle, 21 October 1691, in The correspondence of John Locke, ed. by E. S. de Beer (8 vols, Oxford, 1976-89), iv, letter no. 1422. For Boyle's tendency to lose papers, see Boyle, Works (ref. 95), i, pp. xxviii-xxix, and Knight, "Organizing natural knowledge" (ref. 9), 89-94.

97. Boyle, "The preface", History of the air, in Works (ref. 95), xii, 9-11, p. 10.

98. [John Locke], "Advertisement of the publisher to the reader", in Boyle, Works (ref. 95), xii, 5. The title Boyle appended to the weather records of another contributor nicely corroborates Locke's concerns: "Mr Townly's Register, if I misremember not.” See Works (ref. 95), xii, 69.

99. Locke's "Register" is entered under "Aer" in the folio-sized commonplace book entitled "Adversaria physcia", Lovelace Collection, Bodleian Library, MS Locke d. 9, pp. 471-531 (starting from the back of the notebook). It appears in History of the air under "Of the weight of the air" (Title XVII). See Boyle, Works (ref. 95), xii, 70-89 (in the original London, 1692 edition, it is on pp. 104-32).

100. Boyle, History of the air, in Works (ref. 95), xii, 155-6. Both remarks are under "Of the air in reference to the generation, life and health of Animals" (Title XL).

101. Boyle, "The preface", History of the air, in Works (ref. 95), xii, 9.

102. The last two empty Heads are "Promiscuous experiments and observations of the air" (Title XLVII) and "Desiderata in the history of the air, and proposals towards supplying them" (Title XLVIII).

103. [Locke], "Advertisement" in Boyle, Works (ref. 95), xii, 5-6. The editors of Boyle's Works (xii, 6, note a) state that it is not clear to which passage of Bacon Locke refers. I am not sure either, although it does bear some relation to the advice to Greville, presumably not available to Locke.

104. Locke to Boyle, 21 October 1691, in Locke, Correspondence (ref. 96), iv, letter no. 1422.

105. Sprat, History (ref. 63), 36, 44, 62-64, 95, 115; also 318-19. For the contrast with Hooke's method of making natural histories, see Wood, "Methodology and apologetics" (ref. 90), 7-8. Presumably, this difference has implications for the appropriate mode of storing information. I touch on this below in relation to Hooke, but it deserves more consideration.

106. See H. W. B. Joseph, An introduction to logic (2nd edn, Oxford, 1916). For pertinent complications, see Ian Maclean, "White crows, graying hair, and eyelashes: Problems for natural historians in the reception of Aristotleian logic and biology from Pomponazzi to Bacon", in Historia, ed. by Pomata and Siraisi (ref. 40), 147-79.

107. John Wilkins, Essay towards a real character, and a philosophical language (London, 1668), 289. See pp. 22-288 for his forty genera in tables; also pp. 289-96 for "explication of the foregoing Tables".

108. Bacon, Advancement, in Works (ref. 5), iii, 383-4.

109. Bacon, De augmentis, in Works (ref. 5), iv, 438-9.

110. Bacon, Advancement, in Works (ref. 5), iii, 399-400; De augmentis, Works (ref. 5), iv, 439-40.

See M. M. Slaughter, Universal languages and scientific taxonomy in the seventeenth century (Cambridge, 1982), 88-97.

111. There is a considerable body of work on universal languages. In addition to other publications I cite, see for example, Hans Aarsleff, "Wilkins", in Dictionary of scientific biography, reprinted in his From Locke to Saussure: Essays on the study of language and intellectual history (London, 1982), 239-77; James Knowlson, Universal language schemes in England and France 16001800 (Toronto, 1975); Umberto Eco, The search for the perfect language (Oxford, 1995); and Japp Maat, Philosophical languages in the seventeenth century: Dalgarno, Wilkins, Leibniz 
(Dordrecht, 2004).

112. Wilkins, Essay (ref. 107), 21; also "Epistle", sig. a1v.

113. Nehemiah Grew, who catalogued the Royal Society collection, agreed with Wilkins's approach to classification: "So that the Names of Things should always be taken from something more observably declarative of their Form, or Nature." Nehemiah Grew, Musaeum Regalis Societatis (London, 1681), "The preface". See also Sprat, History (ref. 63), 251 for the point that Hooke had begun this; and 113 for the much-quoted endorsement of what Wilkins's "character" might support: the communication of "many things, almost in an equal number of words".

114. John Wilkins, Mercury, or the secret and starry messenger (London, 1641), 56. At this stage, Wilkins was thinking in terms of a language based on a limited number of radical words from an existing natural language, possibly Hebrew. Only in the Essay (1668) did he adopt the approach of matching words to a classification of things and notions. See Benjamin DeMott, "The sources and development of John Wilkins' philosophical language", Journal of English and Germanic philology, lvii (1958), 1-13, pp. 1-2.

115. Wilkins, Essay (ref. 107), 453-4.

116. "Of an universall reall caracter", in Francis Lodwick's Commonplace Book, BL, MS Sloane: 897, ff. 32r-39v. The entire notebook consists of 43 folios. This part is printed in Salmon, Francis Lodwick (ref. 19), 223-30, p. 224. See William Poole, "The divine and the grammarian: Theological disputes in the 17th-century universal language movement", Historiographica linguistica , xxx (2003), 273-300 on Lodwick; and also on the different interpretations of Biblical and theological accounts of language.

117. On Kinner, see Young, Comenius (ref. 82), 382-440.

118. Cited in Benjamin DeMott, 'Science versus mnemonics: Notes on John Ray and on John Wilkins' Essay toward a real character, and a philosophical language", Isis, xlviii (1957), 3-12, p. 7; and full Latin text of letter in DeMott, "Wilkins' philosophical language" (ref. 114), 11-13.

119. DeMott, "Wilkins' philosophical language" (ref. 114), 6. For Kinner's influence on Wilkins, see DeMott, "Science versus mnemonics" (ref. 118), 7-8; and Slaughter, Universal languages (ref. 110), 131-5.

120. DeMott, "Wilkins' philosophical language" (ref. 114), 8-9, for comment on this in Hartlib's Ephemerides of 1650.

121. [Seth Ward], Vindicae academiarum (Oxford, 1654), 20-21. Reprinted in Allen G. Debus, Science and education in the seventeenth century: The Webster-Ward debate (New York, 1970). For an acknowledgement of Ward's advice, see Wilkins, Essay (ref. 107), "To the reader", sig. b2r. Ward's approach to the construction of an artificial language differed from that of Wilkins, and this disparity surfaced in later discussions. See Rhodri Lewis, "The efforts of the Aubrey correspondence group to revise John Wilkins' Essay (1668) and their context”, Historiographia linguistica, xxviii (2001), 331-64.

122. Petty, Advice (ref. 80), 4.

123. Petty, Advice (ref. 80), 3 (no. 8). In 1687 Petty claimed to be able "at first hearing remember any 50 Nonsensical Incoherent words", but admitted that this was "of noe use but to gett the admiration of ffoolish people". See Letter, William Petty to Robert Southwell, 16 August 1687, in The Petty-Southwell correspondence 1676-1687, edited from the Bowood Papers by the Marquis of Landsdowne (New York, 1967; 1st publ. 1928), 282-4.

124. See P. J. Wallis, "An early mathematical manifesto: John Pell's Idea of mathematics", The Durham research review, xviii (1967), 139-48. I use Wallis's transcription of the copy of the English Broadsheet of Pell's Idea (at pp. 141-5) found in British Library, shelfmark: 528.n.20; it is bound with a copy of Pell's Tabula numerorum quadratorum (1672). There was also a Latin version, entitled as both "Ideae mathematicae" and "Idea matheseos". Petty mentioned Pell's work as an indication of his more general "Advice": "for the more explicit understanding of our Meaning 
herein, we refer to Mr. Pell's most excellent Idea thereof [i.e. of mathematics] written to Master Hartlib". See Petty, Advice (ref. 80), 5.

125. Aubrey said that Pell "communicated to his friends his excellent Idea matheseos in half a sheet of paper". Aubrey, Brief lives (ref. 29), 230. See Noel Malcolm, "The life of John Pell”, in Noel Malcolm and Jacqueline Stedall, John Pell (1611-1685) and his correspondence with Sir Charles Cavendish: The mental world of an early modern mathematician (Oxford, 2005), 12-244, pp. 65-76 for the "Idea" and its distribution via intermediaries. On Haak, see Dorothy Stimson, "Hartlib, Haak, and Oldenburg: Intelligencers", Isis, xxxi (1940), 309-26.

126. [John Pell], "An idea of mathematicks, long since written by Dr. John Pell”, in Philosophical collections, ed. by Robert Hooke (no. 5, London, February 1681/82), 127-34. See pp. 135-45 for letters from Mersenne, Pell and Descartes.

127. Bacon, Advancement, in Works (ref. 5), iii, 406.

128. Pell, Idea, in Wallis, op. cit. (ref. 124), 142-3.

129. Ibid., 144. A similar claim that this might be the task of "one man" occurs in Pell's letter to Thomas Goad, 7 August 1368, cited in Malcolm, "Life of Pell" (ref. 125), 65-66. Malcolm suggests that Pell was angling for employment.

130. $O E D$ (ref. 3) records the earliest usage of "pocket-booke" in 1617. The first title recorded containing this term, as given in Early English Books Online (www.eebo.chadwyck.com), was published in 1661. The notion of "Pocket-learning" had a negative connotation in John Selden's Historie of tithes (1618); cited in Feingold, "English Ramism" (ref. 22), 163.

131. Pell, Idea (ref. 124), 144-5. For Beale's interest in this point, see Lewis, "Best mnemonicall expedient" (ref. 13), 125-6.

132. Printed in Wallis, "An early mathematical manifesto" (ref. 124), 145-7.

133. Letter, Descartes to Cornelis van Hogelande, 8 February 1640, in Descartes, Philosophical writings (ref. 14), iii, 144-5; see the original Latin version in Hooke, Philosophical collections (ref. 126), 144-5. See also a partial translation of this letter in Wallis, "An early mathematical manifesto" (ref. 124), 147. Malcolm, "Life of Pell" (ref. 125), 72, explains that Hogelande forwarded this letter to Haak.

134. A Dutch translation appeared in 1684, and the first Latin translation in 1701. See Stephen Gaukroger, Descartes: An intellectual biography (Oxford, 1995), 111-15, 434.

135. Descartes, "Rules for the direction of the mind", Rule Sixteen, in Philosophical writings (ref. 14), i, 67. In Rule Seven, Descartes explained that he rehearsed chains of deduction several times "until I have learnt to pass from the first to the last so swiftly that memory is left with practically no role to play, and I seem to intuit the whole thing at once. In this way our memory is relieved, the sluggishness of our intelligence redressed, and its capacity in some way enlarged" (p. 25).

136. Some parts of the Regulae were included in Antoine Arnauld and Pierre Nicole, La logique, ou l'art de penser (2nd edn, Paris, 1664). This was translated into English in 1685. See Mary B. Hesse, "Hooke's philosophical algebra", Isis, lvii (1966), 67-83, p. 80 n. 36.

137. Wilkins, Essay (ref. 107), 441. It is plausible to consider Wilkins's schema as externalized mental scaffolding that might supplement, or stimulate, content stored in the brain. In recent cognitive psychology, the "extended mind" hypothesis suggests that brain processes extend into the world when we use tools of various kinds, such as images on stone, writing on paper, or files in a computer. See, for example, Andy Clark and David Chalmers, "The extended mind", Analysis, lviii (1998), 7-19; Mark Rowlands, Externalism: Putting mind and world back together again (Chesham, 2003); and Andy Clark, Natural-born cyborgs (Oxford, 2003).

138. Letters, Andrew Paschall to John Aubrey, 11 June 1678 and 8 July 1678, Bodleian MS Aubrey 13, ff. 31-32, cited in A. J. Turner, "Andrew Paschall's tables of plants for the universal language, 1678”, Bodleian Library record, ix (1978), 346-50, pp. 349-50.

139. Letter, Aubrey to Ray, 9 July 1678, in Ray, Philosophical letters (ref. 42), 144-5; and Slaughter, 
Universal languages (ref. 110), 177.

140. Wilkins, Essay (ref. 107). 21. On this crucial point, see Letter, Descartes to Mersenne, 20 November 1629, Philosophical writings (ref. 14), iii, 10-13.

141. Letter, Wilkins to Willughby, 20 October 1666, in Ray, Philosophical letters (ref. 42), 366-7.

142. Slaughter, Universal languages (ref. 110), 163-70, p. 176; also Clark Emery, “John Wilkins' universal language", Isis, xxxviii (1948), 174-85.

143. Letter, Ray to Martin Lister, 7 May 1669, in Ray, Philosophical letters (ref. 42), 45-48, p. 47: for example, "sed ad Autoris methodum praescriptam Plantas accommodare ...". This translation of the Latin is given in DeMott, "Science versus mnemonics" (ref. 118), 5; also Charles Raven, John Ray: Naturalist (Cambridge, 1942), 182. Ray was still complaining early the next year: see Ray to Martin Lister, 28 April 1670 (pp. 62-63).

144. Wilkins, Essay (ref. 107), 22.

145. This is covered in several publications. See Slaughter, Universal languages (ref. 110), 189-212; David A. Givner, "Scientific preconceptions in Locke's philosophy of language", Journal of the history of ideas, xxiii (1962), 340-54; Peter Alexander, Ideas, qualities, and corpuscles: Locke and Boyle on the external world (Cambridge, 1985), chap. 13; and A. J. Cain. "John Locke on species", Archives of natural history, xxiv (1997), 269-92.

146. Locke, Essay (ref. 34), III.vi.9.

147. Ibid., III.xi.2. For a similar criticism, see [Thomas Baker], Reflections upon learning (2nd edn, London, 1700; 1st publ. 1699), 17-18. However, when his friend, Nicolas Toinard, asked him about George Dalgarno's Ars signorum (1661), Locke recommended that he look at Wilkins's book. See Letter, Locke to Nicolas Toinard, 30 August 1681, in Locke, Correspondence (ref. 96), ii, letter no. 656.

148. Phillip R. Sloan, "John Locke, John Ray, and the problem of natural systems", Journal of the history of biology, v (1972), 1-53, pp. 21-26. More recently, see Peter R. Anstey and Stephen A. Harris, "Locke and botany", Studies in history and philosophy of biological and the biomedical sciences, xxxvii (2006), 151-71.

149. John Ray, The wisdom of God manifested in the works of the creation (2nd edn, London, 1692), 2; see Charles Webster, "John Ray", in Dictionary of scientific biography, xi, 313-18, p. 314.

150. Locke, Essay (ref. 34), III.xi.7; Slaughter, Universal languages (ref. 110), chap. 9.

151. Robert Hooke, A description of helioscopes (London, 1676), 31. See also Robert Hooke, "Some observations and conjectures concerning the Chinese characters", Philosophical transactions, xvi (1686), 63-78. For Hooke's conversations about universal languages, see Robert Hooke, The diary of Robert Hooke, 1672-1680, ed. by H. W. Robinson and W. Adams (London, 1968), 69, 76-77, 84, 177-420, 430-1, 435 and many other entries between 1673 and 1680. On his debt to Wilkins, see Lisa Jardine, The curious life of Robert Hooke: The man who measured London (London, 2003), 73-77.

152. See Richard Waller, "The life of Robert Hooke", in The posthumous works of Robert Hooke, ed. by Richard Waller (London, 1705), pp. i-xxviii, p. i. The Diary is in the Guidhall Library, MS 1758. The paperbook he used for the diary seems to have been acquired from the Royal Society, since one end of it has entries pertaining to his curatorial duties. See Lotte Mulligan, "Self-scrutiny and the study of nature: Robert Hooke's diary as natural history", Journal of British studies, xxxv (1996), 311-42, p. 320. The view that note-taking improved memory was common, although there was a counter opinion. See, for example, this estimate of Seth Ward: "The Bishop had an ill Memory, even when he was in his best Health, which he empaird, by commiting all things to writing." Walter Pope, The life of Seth Ward, ed. by J. B. Bamborough (Oxford, 1961; 1st publ. 1697), 192; and 194-5 on his final loss of memory.

153. Hooke, September 1672, Diary (ref. 151), 7: "bought August Transactions, Streets book of mnemonick verses, both 1 sh." 
154. On 11 September 1677 , Hooke made a diary entry about treating "a bad memory and severall other distempers" by swallowing "very fine filings of the best refined silver". Hooke, Diary (ref. 151), 311-12. For the full range of self-experimentation, see Lisa Jardine, "Hooke the man: His diary and his health", in Jim Bennett, Michael Cooper, Michael Hunter and Lisa Jardine, London's Leonardo: The life and work of Robert Hooke (Oxford, 2003), 163-206.

155. Aubrey, Brief lives (ref. 29), 165.

156. Robert Hooke, "A general scheme, or idea of the present state of natural philosophy", in Posthumous works (ref. 152), 1-70, p. 5. Hesse, "Hooke's philosophical algebra" (ref. 136), 68 dates its composition as 1666; Wood, "Methodology and apologetics" (ref. 90), 24 n. 45 argues for 1665.

157. See the interpretations in Stephen Gaukroger, Descartes' system of natural philosophy (Cambridge, 2002), 204-6; and Desmond Clarke, Descartes's theory of the mind (Oxford, 2003), 91-99. For the significance of localized versus distributed, and representational versus dispositional, memory, see John Sutton, Philosophy and memory traces: Descartes to connectionism (Cambridge, 1998).

158. [Henry Barker], The polite gentleman; or, reflections upon the several kinds of wit (London, 1700), 64-65. On this text, see Roger D. Lund, "Wit, judgment, and the misprisions of similitude", Journal of the history of ideas, lxviii (2004), 53-74.

159. [Barker], Polite gentleman (ref. 158), 67-70. Locke's unusual formulation should be noted here: whereas "wit" was normally used as a synonym for understanding (for example, by Hooke), Locke used it to denote clever humour or banter, assisted by a quick memory; he contrasted this unfavourably with "Reason and Judgment". See Locke, Essay (ref. 34), II.xi.2. But this did not affect agreement on the contrast between memory and reason.

160. See B. R. Singer, "Robert Hooke on memory, association and time perception", Notes and records of the Royal Society of London, xxxi (1976), 115-31; Jamie C. Kassler, Inner music: Hobbes, Hooke and North on internal character (London, 1995), chap. 3.

161. Lotte Mulligan, "Robert Hooke's 'memoranda': Memory and natural history", Annals of science, xlix (1992), 47-61; and "Self-scrutiny" (ref. 152), 311-42.

162. Robert Hooke, Micrographia, or, some physiological descriptions of minute bodies made by magnifying glasses (London, 1665), "The preface", sig. b1v alludes to "another Discourse", which must be "A general scheme".

163. Hooke, Micrographia (ref. 162), "The preface", sig. a1r and a2r and v.

164. Ibid., "The preface", sig. b2r. Hooke used various synonyms for reason, almost interchangeably: thus in a manuscript of 21 April 1692, he refers to "the Intellect and the mind \& judgment". See the transcription of Trinity College, Cambridge, MS: O.11a.114, in D. R. Oldroyd, "Some 'Philosophicall Scribbles' attributed to Robert Hooke", Notes and records of the Royal Society of London, xxxv (1980), 17-32, pp. 29-30. Note that "Philosophicall Scribbles" (MS: O.11a.128) is the item that Oldroyd transcribes in full.

165. Hooke, Micrographia (ref. 162), "The preface", sig. a1v; emphasis in original.

166. Ibid., "The preface", sig. b1v.

167. Ibid., "The preface", sig. b2r.

168. Hooke's preface to Pitt's The English atlas (London, 1680) is in BL, Sloane MS: 1039, f. 1. This did not appear in the published version.

169. Sprat, History (ref. 63), 175-79, p. 175; and p. 179 for the chart: "A Scheme at one View representing to the Eye the Observations of the Weather for a Month."

170. "Mr. Hooke's analysis of the whole businesse of navigation under the title of hydrographie", Bodleian MS Rawlinson: A. $171 \mathrm{ff}$. 245, 246v. This is dated 23 March 1685/86.

171. Hooke, "General scheme" (ref. 156), 64. For relevant discussion, see John T. Harwood, "Rhetoric and graphics in Micrographia", in Robert Hooke: New studies, ed. by Michael Hunter and Simon Schaffer (Woodbridge, 1989), 119-47, pp. 134-47. 
172. Hooke, "General scheme" (ref. 156), 64. Compare Seth Ward's comment (see ref. 86).

173. Ibid., 7, 61. Waller interpolated: "This I think Dr. Hook never wrote” (pp. 5-6).

174. Ibid., 5-6.

175. Ibid., 6-7.

176. Ibid., 18, 8; also 61 for another statement about this method. See Hesse, "Hooke's philosophical algebra" (ref. 136); and Lotte Mulligan, "Robert Hooke and certain knowledge", Seventeenth century, vii (1992), 151-69.

177. Hooke, "General scheme" (ref. 156), 18.

178. Significantly, in endorsing Bacon's criticism of the ancients, Hooke paused to say that "I do not here altogether reject Logick, or the way of Ratiocination already known; as a thing of no use. It has its peculiar Excellencies and Uses ... and affords some Helps to some kinds of Invention ... as well as to the Memory, by its Method" (ibid., 5-6).

179. Ibid., 34 .

180. Letter, Robert Hooke to G. W. Leibniz, 15 May 1681, Royal Society of London, Letter Book, EL/H3/64. Hooke went on to call this "the Algebra of Algebras or the Science of methods". He envisaged a real character, based on a reduction of things and notions to primitive natural kinds, as a part of this yet to be achieved "Generall method".

181. See the table in Hooke, "General scheme" (ref. 156), 22-26. On the close links with Bacon's method, see Michael Hunter, "Hooke the natural philosopher", in Bennett et al., London's Leonardo (ref. 154), 119-22; and, more generally, Anstey, "Locke, Bacon” (ref. 60).

182. For earlier lectures in this series, see Robert Hooke, Lectiones Cutlerianae, or a collection of lectures (London, 1679). Hooke's account of memory appeared in a lecture on 21 June 1682. See his "Lectures of light, explicating its nature, properties, and effects", in Posthumous works, ed. by Waller (ref. 152), Section VII, 138-48, 143-4. See Singer, "Hooke on memory" (ref. 160); and Oldroyd, "Some 'Philosophical Scribbles"” (ref. 164), 17-32, for an undated manuscript bearing on related topics.

183. For Hooke's likely debts to Hobbes and Thomas Willis, see Oldroyd, "Some 'Philosophical Scribbles"” (ref. 164), 24-25. For accounts of Hooke's physicalist theory of memory, see Graham Richards, Mental machinery: The origins and consequences of psychological ideas, Part 1: 1600-1850 (London, 1992), 67-69; Douwe Draaisma, Metaphors of memory: A history of ideas about the mind (Cambridge, 2000), 56-61, and his "Hooke on memory and the memory of Hooke", in Robert Hooke: Tercentenary studies, ed. by Michael Cooper and Michael Hunter (Aldershot and Burlington, 2006), 111-21.

184. Hooke, "Lectures of light" (ref. 182), 138-48, pp. 143-4. Boyle expressed amazement that the memory of a "learned man" could retain so much information. If memory is a "corporeal faculty" dependent on "distinct traces, footsteps, impressions" in the brain, how can "this vast multitude of exceedingly various things" be stored and found again? Robert Boyle, The Christian virtuoso: The second part [1691-92], in Works (ref. 95), xii, 427-530, p. 463.

185. Hooke, "Lectures of light" (ref. 182), 140. On Hooke's weather clock as an analogue of memory, see Nick Wilding, "Graphic technologies", in Robert Hooke, ed. by Cooper and Hunter (ref. 183), 123-34, p. 124.

186. Hooke, "General scheme" (ref. 156), 140. Hooke did not specifically mention association of ideas as one of the problems; on this see Hobbes, Leviathan (ref. 39), chap. III, 20, for the danger of trains of thought; also Richard Yeo, "Before Memex: Robert Hooke, John Locke, and Vannevar Bush on external memory", Science in context, xx (2007), 1-27.

187. See Robert Hooke, "Mathematical language", Royal Society classified papers, xx, no. 72 (undated), cited in Slaughter, Universal languages (ref. 110), 183.

188. See the undated manuscript in Hooke's hand entitled "Lectures of things requisite to a Ntral History", 
Royal Society of London, Classified Papers, CI.P/20/50a, ff. 99-109. This is transcribed in D. R. Oldroyd, "Some writings of Robert Hooke on procedures for the prosecution of scientific enquiry", Notes and records of the Royal Society of London, xli (1987), 145-67; transcription at pp. 151-9; quotation, p. 155.

189. Hooke, "General scheme" (ref. 156), 21.

190. Ibid., 64, 42. For a similar rejection of "Needless philology, avoyding also the citations of all kinds of authors \& opinions", see Hooke, "Lectures of things requisite to a natural history", in Oldroyd, "Some writings of Hooke" (ref. 188), 155.

191. Hooke, "General scheme" (ref. 156), 63. For his own concerns about remembering details, see Hooke, Diary (ref. 151), 12 July 1675: "I have forgot most particulars of this week."

192. Hooke, "General scheme" (ref. 156), 18. In an undated paper printed by William Derham as "Dr. Hook's method of making experiments", there is a prescription "to register the whole Process of the Proposal, Design, Experiment, Success, or Failure”. See Robert Hooke, Philosophical experiments and observations of the late eminent Dr. Robert Hooke ... publish'd by W. Derham (London, 1726), 26-28, p. 27.

193. Hooke, "General scheme" (ref. 156), 21. This is close to Locke's allusion to Bacon's advice (see ref. 103).

194. Ibid., 62.

195. Ibid., 20-21.

196. Hooke, Micrographia (ref. 162), "The preface", sig. d1r.

197. A comparison of Hooke's note taking with both earlier methods and the putative innovations of his contemporaries is beyond the scope of this article, but see Richard Yeo, "John Locke's 'Of Study' (1677): Interpreting an unpublished essay", Locke studies, iii (2003), 147-65 and "John Locke's 'New Method' of commonplacing: Managing memory and information", Eighteenthcentury thought, ii (2004), 1-38.

198. The other side of this was secrecy and credit, since accurate records allowed priority claims. See Rob Iliffe, "'In the warehouse': Privacy, property and priority in the early Royal society”, History of science, $\mathrm{xxx}$ (1992), 29-68.

199. The following quotations are found in Hooke, "General scheme" (ref. 156), 63-65.

200. In the "General scheme" (ref. 156), Hooke was mainly interested in what might be called the prepublication stage: collection, arrangement of material, comparison, and inferences. Once papers were recorded in the "Register", or published in the Transactions, he advised yet another sifting and collating process, again using commonplace method and different notebooks (journal, ledger etc). See "Proposals concerning the arrangement \& of the publications of the R. society", Royal Society of London, Classified Papers, CI.P/20/97 (not in Hooke's hand). For the degree of control he envisaged, see Adrian Johns, The nature of the book: Print and knowledge in the making (Chicago, 1998), 484-89; Wilding, "Graphic technologies" (ref. 185), 131-3. Of course, Hooke was not alone in these concerns. See Michael Hunter, Establishing the new science: The experience of the early Royal Society (Woodbridge, 1989), 4, 45-71; and Mordechai Feingold, "Of records and grandeur: The archive of the Royal Society", in Archives of the scientific revolution: The formation and exchange of ideas in seventeenth-century Europe, ed. by Michael Hunter (Woodbridge, 1998), 171-84.

201. Waller, "Life of Hooke", in Posthumous works (ref. 152), p. iii.

202. Sprat, History (ref. 63), 119. Curiously, on the very next page, Sprat mentions "the dreadful firing of the City" of London and loss of "many Books".

203. A. J. Cain, "Logic and memory in Linnaeus's system of taxonomy", Proceedings of the Linnean Society of London, xlix (1958), 144-63, p. 156.

204. See the citations from Buffon's Histoire naturelle générale et particulière (Paris, 1787), in De Renzi, "Writing and talking of exotic animals" (ref. 41), 162; and Rossi, Logic (ref. 24), 172. 
46 - RICHARD YEO

205. D’Alembert, Preliminary discourse (ref. 37), 144-5; "Histoire", in Encyclopédie, ed. by Denis Diderot and Jean le Rond d'Alembert (17 vols, Paris, 1751-80), viii, 220-30, pp. 220-1, cited in Brian Ogilvie, "Natural history, ethics, and physico-theology", in Historia, ed. by Pomata and Siraisi (ref. 40), 75-103, p. 98.

206. Rossi, Logic (ref. 24), 172, citing "Botanique", in Encyclopédie (ref. 205), ii, 340-5, p. 342. 